\title{
Cloud condensation nuclei activity, droplet growth kinetics, and hygroscopicity of biogenic and anthropogenic secondary organic aerosol (SOA)
}

\author{
D. F. Zhao ${ }^{1}$, A. Buchholz ${ }^{1, \text { a }}$, B. Kortner ${ }^{1}$, P. Schlag ${ }^{1}$, F. Rubach ${ }^{1, b}$, H. Fuchs ${ }^{1}$, A. Kiendler-Scharr ${ }^{1}$, R. Tillmann ${ }^{1}$, \\ A. Wahner ${ }^{1}$, A. K. Watne ${ }^{2}$, M. Hallquist ${ }^{2}$, J. M. Flores $^{3}$, Y. Rudich ${ }^{3}$, K. Kristensen ${ }^{4}$, A. M. K. Hansen ${ }^{4}$, M. Glasius ${ }^{4}$, \\ I. Kourtchev ${ }^{5}$, M. Kalberer ${ }^{5}$, and Th. F. Mentel ${ }^{1}$ \\ ${ }^{1}$ Institute for Energy and Climate Research, IEK-8: Troposphere, Forschungszentrum Jülich, 52425 Jülich, Germany \\ ${ }^{2}$ Department of Chemistry and Molecular Biology, University of Gothenburg, Gothenburg, 41296, Sweden \\ ${ }^{3}$ Department of Earth and Planetary Sciences, Weizmann Institute of Science, Rehovot, 76100, Israel \\ ${ }^{4}$ Department of Chemistry, Aarhus University, 8000 Aarhus, Denmark \\ ${ }^{5}$ Department of Chemistry, University of Cambridge, Cambridge, CB2 1EW, UK \\ ${ }^{a}$ now at: Department of Applied Physics, University of Eastern Finland, 70211 Kuopio, Finland \\ bnow at: Max-Planck-Institute for Chemistry, Mainz, Germany \\ Correspondence to: Th. F. Mentel (t.mentel@fz-juelich.de)
}

Received: 27 June 2015 - Published in Atmos. Chem. Phys. Discuss.: 21 July 2015

Revised: 1 January 2016 - Accepted: 17 January 2016 - Published: 1 February 2016

\begin{abstract}
Interaction of biogenic volatile organic compounds (VOCs) with Anthropogenic VOC (AVOC) affects the physicochemical properties of secondary organic aerosol (SOA). We investigated cloud droplet activation (CCN activity), droplet growth kinetics, and hygroscopicity of mixed anthropogenic and biogenic SOA (ABSOA) compared to pure biogenic SOA (BSOA) and pure anthropogenic SOA (ASOA). Selected monoterpenes and aromatics were used as representative precursors of BSOA and ASOA, respectively.

We found that BSOA, ASOA, and ABSOA had similar $\mathrm{CCN}$ activity despite the higher oxygen to carbon ratio $(\mathrm{O} / \mathrm{C})$ of ASOA compared to BSOA and ABSOA. For individual reaction systems, $\mathrm{CCN}$ activity increased with the degree of oxidation. Yet, when considering all different types of SOA together, the hygroscopicity parameter, $\kappa_{\mathrm{CCN}}$, did not correlate with $\mathrm{O} / \mathrm{C}$. Droplet growth kinetics of BSOA, ASOA, and ABSOA were comparable to that of $\left(\mathrm{NH}_{4}\right)_{2} \mathrm{SO}_{4}$, which indicates that there was no delay in the water uptake for these SOA in supersaturated conditions.

In contrast to $\mathrm{CCN}$ activity, the hygroscopicity parameter from a hygroscopic tandem differential mobility analyzer (HTDMA) measurement, $\kappa_{\mathrm{HTDMA}}$, of ASOA was distinctively higher $(0.09-0.10)$ than that of BSOA (0.030.06), which was attributed to the higher degree of oxida-
\end{abstract}

tion of ASOA. The ASOA components in mixed ABSOA enhanced aerosol hygroscopicity. Changing the ASOA fraction by adding biogenic VOC (BVOC) to ASOA or vice versa (AVOC to BSOA) changed the hygroscopicity of aerosol, in line with the change in the degree of oxidation of aerosol. However, the hygroscopicity of ABSOA cannot be described by a simple linear combination of pure BSOA and ASOA systems. This indicates that additional processes, possibly oligomerization, affected the hygroscopicity.

Closure analysis of CCN and HTDMA data showed $\kappa_{\text {HTDMA }}$ was lower than $\kappa_{\mathrm{CCN}}$ by $30-70 \%$. Better closure was achieved for ASOA compared to BSOA. This discrepancy can be attributed to several reasons. ASOA seemed to have higher solubility in subsaturated conditions and/or higher surface tension at the activation point than that of BSOA.

\section{Introduction}

Secondary organic aerosol (SOA) is an important class of atmospheric aerosol with impacts on air quality, human health, and climate change (Hallquist et al., 2009; Kanakidou et al., 2005; Jimenez et al., 2009; Zhang et al., 2011; Verma et 
al., 2014). Despite substantial improvements in the understanding of SOA formation mechanisms and properties, considerable uncertainties remain about the regional and global budget of SOA (e.g., Goldstein and Galbally, 2007). Models often do not correctly predict the ambient concentrations of organic aerosol (OA) (e.g., Spracklen et al., 2011; Heald et al., 2005), and usually the modeled concentrations underestimate the observed OA concentrations (Spracklen et al., 2011). Recent studies suggested that interactions between biogenic volatile organic compounds (VOCs) and anthropogenic emissions can enhance SOA formation and often, ambient OA concentrations correlate with anthropogenic tracers such as CO or isopropyl nitrate (de Gouw et al., 2005, 2008; Weber et al., 2007; Shilling et al., 2013; Xu et al., 2015). However, ${ }^{14} \mathrm{C}$ carbon isotopic analysis showed that the SOA material itself is composed mostly of modern carbon, i.e., arises from biogenic sources, including biomass burning (Weber et al., 2007; Zotter et al., 2014). These observations suggest that a consideration of an anthropogenic enhancement can reduce the discrepancies between models and observations (de Gouw et al., 2005; Goldstein et al., 2009; Hoyle et al., 2011; Worton et al., 2011; Glasius et al., 2011).

Anthropogenic VOCs (AVOCs), such as aromatic compounds are possibly important factors that lead to enhanced SOA formation as their oxidation products can interact with biogenic VOC (BVOC) oxidation products during SOA formation, as shown by several studies (Hoyle et al., 2011; Emanuelsson et al., 2013; Flores et al., 2014). In a recent study, Emanuelsson et al. (2013) found that anthropogenic SOA (ASOA) components reduce the volatility of biogenic SOA (BSOA) in a non-linear way with respect to the ASOA fraction, possibly by oligomerization or a phase change such as formation of a glassy state (Emanuelsson et al., 2013; Virtanen et al., 2010; Koop et al., 2011). The reduced volatility in the mixed SOA (anthropogenic-biogenic SOA, ABSOA) can enhance SOA persistence and concentrations in the atmosphere. Flores et al. (2014) investigated the optical properties of BSOA, SOA from simultaneous addition of BVOC and AVOC and SOA from sequential addition of BVOC and AVOC. They found that both SOA from mixed AVOC and BVOC show an increase of scattering component of the refraction index with aging (increase of the oxygen to carbon ratio $(\mathrm{O} / \mathrm{C}))$ and the increase is greater for SOA from simultaneous addition of BVOC and AVOC than SOA from sequential addition of VOC.

Besides the thermochemical and optical properties, cloud droplet activation (cloud condensation nuclei (CCN) activity) and hygroscopicity are important physicochemical properties that have critical implications for the impact of aerosol on climate. It is possible that enhanced oligomerization, which happens in the mixed aerosol particles could modify its CCN activity and hygroscopicity (Xu et al., 2014). Given that CCN activity and hygroscopicity correlate with the aerosol O/C in many cases and given that ASOA tends to have a higher O/C (Chhabra et al., 2011; Emanuelsson et al., 2013), it is expected that ASOA components enhance the $\mathrm{CCN}$ activity and hygroscopicity of mixed SOA. However, to the best of our knowledge, the influence of the interaction of AVOC with BVOC on CCN activity and hygroscopicity of SOA has not been studies from the literature.

Several field studies found a delay in droplet growth kinetics of the aerosol from anthropogenic origin when compared with the aerosol from biogenic origin (Shantz et al., 2010, 2012). ASOA, as an important anthropogenic aerosol, may contribute to this delay. In addition, a recent laboratory study suggests limited mixing in SOA formed by sequentially mixing a biogenic precursor ( $\alpha$-pinene) with an anthropogenic one (toluene) (Loza et al., 2013). It is possible that limited mixing could affect water uptake by ABSOA and delay droplet growth when the diffusion of water within aerosol particle was suppressed. Yet, no laboratory studies on the droplet growth kinetics of ASOA and ABSOA have been found.

In this study, we investigated the effect of the interaction of ASOA and BSOA on CCN activity and hygroscopicity of aerosol. We also studied the kinetics of droplet growth of ASOA, BSOA, and mixed ABSOA.

\section{Experimental}

\subsection{Experiment setup and instrumentation}

The experiments were conducted in the atmosphere simulation chamber SAPHIR (Simulation of Atmospheric PHotochemistry In a large Reaction chamber). SAPHIR is a double-wall Teflon chamber with a volume of $270 \mathrm{~m}^{3}$. Details of the chamber have been previously described (Rohrer et al., 2005; Bohn et al., 2005). The chamber uses natural sunlight for illumination and is equipped with a louvre system, which can be used to simulate dark processes. For the experiments described here, various instrumentations were used to characterize gas phase and the particulate phase species.

Chamber parameters like temperature, relative humidity, flow rate, and photolysis frequencies were also recorded. The actinic flux and the corresponding photolysis frequencies were provided from measurements using a spectral radiometer (Bohn et al., 2005; Bohn and Zilken, 2005).

The number concentration and size distributions of aerosol were measured by a scanning mobility particle sizer (SMPS; DMA model 3081/CPC model 3785, TSI Shoreview, USA) and separate condensation particle counter (CPC; model 3786 , TSI) to allow for detection of nucleation particles down to $3 \mathrm{~nm}$.

The chemical composition of aerosol was measured by a high-resolution time-of-flight aerosol mass spectrometer (HR-ToF-AMS; Aerodyne Research Inc., USA). To characterize the degree of oxidation of aerosol, the oxygen to carbon ratio $\left(\mathrm{O} / \mathrm{C}\right.$ ), and $f_{44}$ (fractional contribution of $m / z 44$ to 
the total organics signal) were obtained from the mass spectra. The $\mathrm{O} / \mathrm{C}$ (corrected for the minor influence of gaseous components) was derived by the elemental analysis of mass spectra obtained in the high mass resolution mode ( $\mathrm{W}$-mode) of the mass spectrometer as described by Aiken et al. (2007) and Aiken et al. (2008). The contributions of gas phase $\mathrm{CO}_{2}$ and water vapor to $m / z 44$ and to $m / z 18$, respectively, were characterized using a $\mathrm{CO}_{2}$ and $\mathrm{H}_{2} \mathrm{O}$ analyzer (Picarro, Santa Clara, USA). The values were subtracted to obtain the particle signals before the elemental analysis (Allan et al., 2004).

Droplet activation and droplet growth were measured using a size scanning CCN method as described previously (Buchholz, 2010; Zhao et al., 2010). This method, also known as Scanning Mobility CCN analysis (SCMA; Moore et al., 2010), has been successfully used in a number of previous studies (Asa-Awuku et al., 2008, 2009, 2010; Padro et al., 2007; Engelhart et al., 2008, 2011). The measurement was done by coupling a differential mobility analyzer (DMA; model 3081, TSI Shoreview, USA) with a cloud condensation nuclei counter (CCNC; Droplet Measurement Technique, USA) and condensation particle counter (CPC3786, TSI). Before entering the instruments, the particles were dried using a silica gel diffusion drier (gradually drying to $\sim 10 \%$ relative humidity, $\mathrm{RH}$ ) with a residence time of around $3 \mathrm{~s}$. Particles then passed through the DMA and the outgoing air was split into two paths connecting to the CCNC and $\mathrm{CPC}$, which measure the $\mathrm{CCN}$ and cloud nuclei $(\mathrm{CN})$ concentrations, respectively. The flow rate of the CCNC is around $0.5 \mathrm{~L} \mathrm{~min}^{-1}$ with a sheath to aerosol flow ratio of 10 . The residence time in the CCN column is around $24 \mathrm{~s}$ with the time in the final supersaturation slightly shorter (Lance et al., 2006). The DMA scanned over a size range between 10 and $450 \mathrm{~nm}$ while the supersaturation (SS) remained constant. And four to five different supersaturations in the range of $0.1-1.3 \%$ were used depending on the particle sizes. From the measurement, $\mathrm{CCN}$ activation fraction over size and the dry activation diameter (or critical dry diameter, $D_{\text {crit }}$ ) were obtained using a method as described in Buchholz (2010). Briefly, for each particle size, the $\mathrm{CN}$ and $\mathrm{CCN}$ concentrations measured were used to calculate the activation fraction $\left(a_{\mathrm{f}}=\mathrm{CCN} / \mathrm{CN}\right)$. Before $a_{\mathrm{f}}$ was calculated, the measured CN and $\mathrm{CCN}$ concentrations were corrected for multiple charged particles. To separate the single from the multiple charged particles, the fraction of multiple charged particles was calculated according to a Boltzmann charge distribution using the measured size distribution (Wiedensohler, 1988). Then, $a_{\mathrm{f}}$ was determined for each charge class separately and fitted with a Gaussian error function (Rose et al., 2008). The dry activation diameter at the set SS is the turning point of this function.

For each SS at least three full scans were performed and the resulting $D_{\text {crit }}$ were averaged. For the calibration of SS, $D_{\text {crit }}$ of ammonium sulfate at various SS was measured and compared to theoretical data in the literature (Rose et al., 2008). The set SS was corrected according to the theoretical data. From the $\mathrm{CCN}$ data, the hygroscopicity parameter $\kappa_{\mathrm{CCN}}$ was calculated according to the one parameter representation of the Köhler equation proposed by Petters and Kreidenweis (2007). The error bars of $\kappa_{\mathrm{CCN}}$ were estimated using the standard deviation of $D_{\text {crit }}$ from three duplicate scans. A higher hygroscopicity parameter $\kappa$ indicates a more hygroscopic material, i.e., cloud droplet activation at lower SS for particles of a given size or at smaller size for a given SS.

The hygroscopic growth of the aerosol was measured using a home-built hygroscopic tandem differential mobility analyzer (HTDMA). The details of the HTDMA were described previously (Buchholz, 2010; Zhao et al., 2010). Particles were selected using the first DMA and then were exposed to a prescribed relative humidity to measure the growth factor. Hygroscopic growth was measured at different RH. The sizes of the humidified particles were determined by the second DMA, which was operated in a scanning mode in combination with a CPC (model 3022A, TSI). The size selected aerosol flow and the sheath air flow of the second DMA were humidified at room temperature $\left(25-30^{\circ} \mathrm{C}\right.$ depending on the surroundings) to almost the same RH with the sheath air at slightly higher RH. The second DMA was kept in a thermo-insulated box, which was cooled to $20^{\circ} \mathrm{C}$. Both aerosol and sheath air flow were cooled down to the same temperature before entering the second DMA, and thus the $\mathrm{RH}$ increased to its final value. The residence time of particles at the final humidity is approximately $30 \mathrm{~s}$ before they entered the SMPS operated with sheath air of the same RH. The hygroscopic growth factor (GF) was calculated as the ratio of the size of the wet particle $\left(D_{\text {wet }}\right)$ to the selected dry size $\left(D_{\text {dry }}\right)$. The HTDMA was calibrated using ammonium sulfate aerosol by comparing with the theoretical growth curve (Rose et al., 2008). From hygroscopic growth factor at $90 \% \mathrm{RH}$, the hygroscopicity parameter, $\kappa_{\text {HTDMA, }}$ was calculated according to Petters and Kreidenweis (2007). The error bars of $\kappa_{\text {HTDMA }}$ were estimated using the standard deviation of the growth factor at $(90 \pm 1) \% \mathrm{RH}$ of at least three duplicate scans.

SOA samples were collected on PTFE (Polytetrafluoroethylene) filters at the end of different experiments to obtain detailed insight into the chemical composition of the aerosol particles. The details of sample collection and analysis are described in Emanuelsson et al. (2013) and Kristensen and Glasius (2011). Before the filters, the air passed through an annular denuder coated with XAD-4 resin to remove gaseous organic species. The filters were extracted and analyzed using a Dionex Ultimate 3000 HPLC system coupled through an electrospray (ESI) inlet to a q-TOF mass spectrometer (micro-TOFq, Bruker Daltonics GmbH, Bremen, Germany), which was operated in both positive and negative mode. Pinonic acid, cis-pinic acid, terpenylic acid, diaterpenylic acid acetate (DTAA) and 3-methyl butane tricarboxylic acid (3-MBTCA) were quantified using authentic standards. 
Table 1. Summary of the experiments in this study.

\begin{tabular}{|c|c|c|c|c|c|}
\hline Experiment no. & $\begin{array}{l}\text { Experiment } \\
\text { type }\end{array}$ & Experiment description & BVOC (ppb) & AVOC (ppb) & $\begin{array}{l}\text { Ozone } \\
\text { added (ppb) }\end{array}$ \\
\hline B1 & BSOA & BVOC only & $\alpha$-pinene, limonene $(20,20)$ & N.A & 50 \\
\hline B3 & BSOA & BVOC only & $\alpha$-pinene, limonene $(48,48)$ & N.A & 200 \\
\hline A 1 & ASOA & AVOC only & N.A & toluene $(85)$ & 0 \\
\hline A2 & ASOA & AVOC only & N.A & toluene (85) & 0 \\
\hline A5 & ASOA & AVOC only & N.A & benzene (280) & 0 \\
\hline A6 & ASOA & AVOC only & N.A & benzene (280) & 0 \\
\hline A7 & ASOA & AVOC only & N.A & p-xylene-d $d_{10}(200)$ & 200 \\
\hline $\mathrm{AB} 1$ & ABSOA & AVOC added $6.3 \mathrm{~h}$ before BVOC & $\alpha$-pinene, limonene $(20,20)$ & p-xylene (30) & 0 \\
\hline $\mathrm{AB} 2$ & ABSOA & AVOC added $6.3 \mathrm{~h}$ before BVOC & $\alpha$-pinene, limonene $(20,20)$ & toluene $(85)$ & 0 \\
\hline
\end{tabular}

For SOA from part of the experiments (experiment nos. B3, AB4, AB6 as in Table 1), samples were also collected on quartz fiber filters and analyzed by ultra-high-resolution mass spectrometry (UHRMS). In this analysis, the aerosol samples were extracted as described elsewhere (Kourtchev et al., 2013). The extracts were analyzed using an ultra-highresolution LTQ Orbitrap Velos mass spectrometer (Thermo Scientific, Bremen, Germany) equipped with a TriVersa Nanomate robotic nanoflow chip-based ESI source (Advion Biosciences, Ithaca NY, USA). The Orbitrap MS instrument calibration, settings, and mass spectral data interpretation are described in Kourtchev et al. (2014). The mass accuracy of the instrument was below $1.5 \mathrm{ppm}$ and the instrument mass resolution was 100000 at $\mathrm{m} / z$ 400. The negative ionization mass spectra were collected in three replicates and in this study, only ions that appeared in all three analytical replicates were kept for evaluation.

The VOCs were measured by a high-resolution proton transfer reaction-mass spectrometer (HR-PTR-MS; Ionicon, Innsbruck, Austria) (Jordan et al., 2009) and gas chromatography coupled to a mass spectrometer (GC-MS; PerkinElmer, Waltham, USA) (Apel et al., 2008; Kaminiski, 2014).

The $\mathrm{OH}$ concentration was measured directly using laserinduced fluorescence (LIF) (Fuchs et al., 2012). The OH radicals inside the chamber are mainly formed by the photolysis of HONO formed via a photolytic process on the chamber walls, and to a minor fraction by $\mathrm{O}_{3}$ photolysis (Rohrer et al., 2005). From the $\mathrm{OH}$ concentration, the $\mathrm{OH}$ dose was calculated and used as a common abscissa in order to better compare different experiments. The $\mathrm{OH}$ dose is the integral $\mathrm{OH}$ concentration over time that gives the accumulated $\mathrm{OH}$ concentrations to which gases and particles were exposed in the course of experiment; $1 \mathrm{~h}$ exposure to a typical atmospheric $\mathrm{OH}$ concentration of $2 \times 10^{6}$ molecules $\mathrm{cm}^{-3}$ is then equivalent to an $\mathrm{OH}$ dose of $7.2 \times 10^{9}$ molecules $\mathrm{cm}^{-3} \mathrm{~s}$.

\subsection{Experimental procedure}

The experimental procedures have been described elsewhere in details (Emanuelsson et al., 2013; Flores et al., 2014) and only a short description is given here. The chamber was typically humidified to $60-70 \% \mathrm{RH}$ in the beginning of the experiment and relative humidity can vary in the range of 30 $70 \%$ due to the ambient temperature change and the dilution by the flow to compensate the sampling loss. In a typical experiment, VOC was added to the chamber and then the roof was opened to start the photooxidation. In some experiments, $\mathrm{O}_{3}$ was added. In all the experiments, particles formed by homogeneous nucleation and no seed was added. In the BSOA experiments, a monoterpene mixture of $\alpha$-pinene and limonene with a molar ratio of $1: 1$ was used as the representative BSOA precursors and its photooxidation induced BSOA formation. Ozone was added to initialize BVOC oxidation and particle formation. In the ASOA experiments, toluene or xylene was used as the representative ASOA precursors. In the mixed SOA experiments (ABSOA), AVOC and BVOC were added, either simultaneously or sequentially to investigate the potential effect of adding order.

In total, three BSOA experiments (including one using $\alpha$ pinene as precursor), seven ASOA experiments, and six mixing experiments (ABSOA) with biogenic and anthropogenic precursors were analyzed in detail and the summary for these experiments is given in Table 1. In two experiments (nos. AB1, AB2), AVOC was added $6.3 \mathrm{~h}$ before the BVOC. In experiments with sequential VOC addition, the second VOC was added $1-2 \mathrm{~h}$ after the SOA mass concentration generated 
from the first addition reached its maximum. Accordingly, the time lag was longer when AVOC was added first due to its lower reactivity. In two experiments (nos. AB3, AB4), BVOC was added 2.5 and $5 \mathrm{~h}$ before the AVOC, respectively. In the other two experiments (nos. AB5, AB6), BVOC and AVOC were added simultaneously into the chamber. In the ABSOA experiments, the mass fraction of ASOA in the total aerosol was estimated using a method based on the aerosol mass yield and VOC consumed as described by Emanuelsson et al. (2013), where ideal mixing of ASOA and BSOA components was assumed. Assuming the same density for ASOA and BSOA, the mass fraction of ASOA is equal to its volume fraction.

\section{Results and discussion}

\subsection{Droplet activation of BSOA, ASOA, and ABSOA}

\subsubsection{Comparison of droplet activation of BSOA, ASOA, and ABSOA}

Droplet activation of BSOA, ASOA and ABSOA at various $\mathrm{SS}$ was parameterized by applying the hygroscopicity parameter $\kappa_{\mathrm{CCN}}$ (Petters and Kreidenweis, 2007). Generally, $\kappa_{\mathrm{CCN}}$ was found to increase slightly with time in the light periods and remained relatively constant or slightly decreased in the dark periods (overview in Fig. S1 in the Supplement). The increase of $\kappa_{\mathrm{CCN}}$ with time in the light period is attributed to photochemical aging, which leads to functionalization, i.e., the formation of oxidized compounds with hydroperoxide, hydroxyl, carbonyl, and carboxylic acid groups (Kroll and Seinfeld, 2008; Zhao et al., 2015b). Photochemical aging is thought to mainly happen in the gas phase (Donahue et al., 2012) and affect the particle composition by partitioning, although heterogeneous oxidation and particle phase oxidation may also play a role. The formation of oxidized compounds with polar functional groups is also supported by the our filter sample analysis of SOA, showing the formation of a number of organic acids, carbonyl compounds and multi-generation compounds such as 3-MBTCA, a tracer for photochemical aging (Zhang et al., 2010; see also Table 3 of Emanuelsson et al., 2013). This functionalization increases the SOA average polarity and thus enhances hygroscopicity (Duplissy et al., 2008; Topping et al., 2005; Suda et al., 2014). We found that $\kappa_{\mathrm{CCN}}$ depended on SS. Since different SS correspond to different critical sizes, this dependence indicates a size-dependent chemical composition of aerosol (Zhao et al., 2015a). When comparing CCN activity of different SOA, $\kappa_{\mathrm{CCN}}$ at similar supersaturation was examined.

The droplet activation of BSOA, ABSOA, and ASOA particles represented by $\kappa_{\mathrm{CCN}}$ is compared for two SS (0.51 and $0.34 \%$ ) in Fig. 1. Different experiments required different ranges of SS because of the achievable particle size ranges. Usually ASOA particles were smaller and thus higher SS
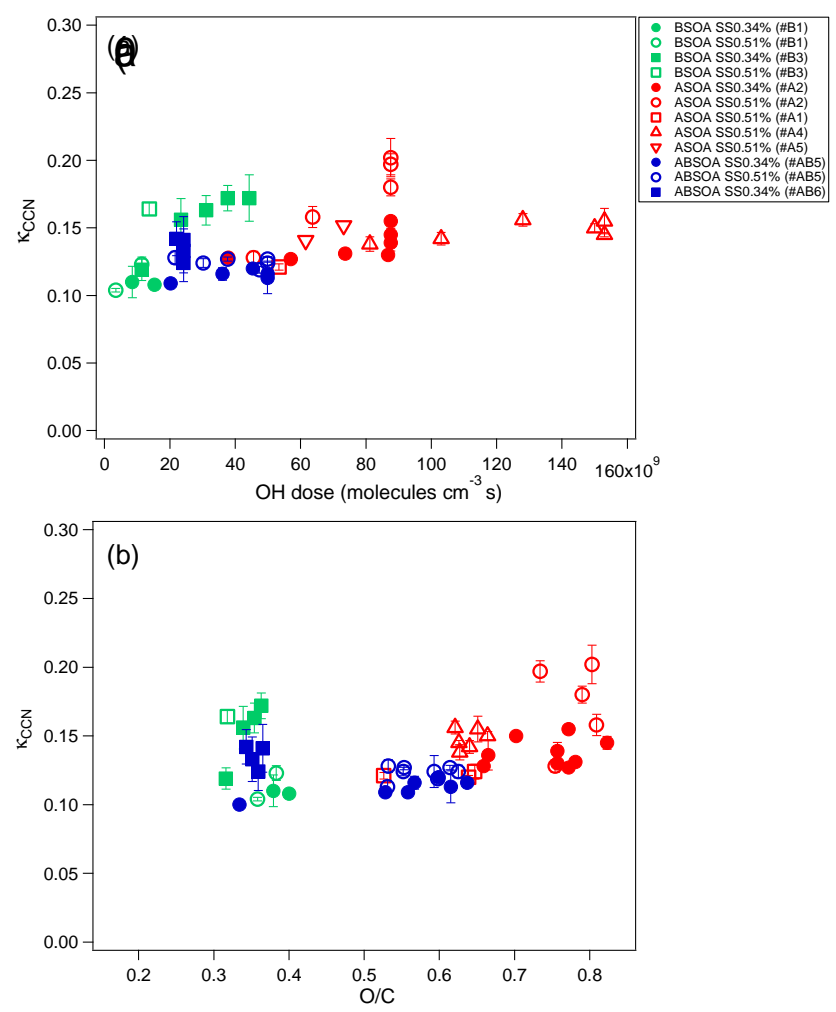

Figure 1. CCN activity of BSOA, ASOA, and ABSOA as a function of $\mathrm{OH}$ dose (a) and $\mathrm{O} / \mathrm{C}$ of aerosol (b). $\kappa_{\mathrm{CCN}}$ at two supersaturations (SS) $0.34 \%$ (solid markers) and $0.51 \%$ (open markers) is shown. The green, red, and blue colors indicate BSOA, ASOA, and ABSOA, respectively. $\kappa_{\mathrm{CCN}}$ at similar SS is compared since $\kappa_{\mathrm{CCN}}$ depended on SS. BSOA, ASOA, and ABSOA showed no significant difference at a given SS. Although ASOA had higher degree of oxidation $(\mathrm{O} / \mathrm{C})$ than BSOA, ASOA components did not enhance $\kappa_{\mathrm{CCN}}$.

were needed to get a proper range of activation fraction to derive $D_{\text {crit }}$. Therefore, we choose $\kappa_{\mathrm{CCN}}$ at two SS in the medium range, 0.34 and $0.51 \%$, to compare between experiments thus maximizing experiments with overlapping SS. In order to compare $\mathrm{CCN}$ activity of different $\mathrm{SOA}$ particles from different experiments, $\kappa_{\mathrm{CCN}}$ is plotted as a function of $\mathrm{OH}$ dose (Fig. 1a), the integral $\mathrm{OH}$ concentration over time to which the particles were exposed. The $\mathrm{CCN}$ activity of the three types of aerosol is generally similar at similar $\mathrm{OH}$ dose. In addition, with exception of $\mathrm{BSOA}, \kappa_{\mathrm{CCN}}$ is largely invariant over a wide range of $\mathrm{OH}$ doses, equivalent to 1-4 days of $\mathrm{OH}$ exposure in the atmosphere (assuming average $\mathrm{OH}$ concentration $2 \times 10^{6}$ molecules $\mathrm{cm}^{-3}$ and $12 \mathrm{~h}$ sunlight per day).

Similarity in CCN activity of ASOA, BSOA, and ABSOA was also observed in the ABSOA experiments with sequential VOC addition, independent of the order of addition of AVOC or BVOC. When BVOC was added after AVOC to the chamber, besides the reaction with $\mathrm{OH}, \mathrm{BVOC}$ also reacted 
with $\mathrm{O}_{3}$ formed previously from photochemical reactions of AVOC. The reaction products from both ozonolysis and $\mathrm{OH}$ oxidation helped to convert ASOA rapidly to ABSOA reaching significant fractions of BSOA (e.g., $70 \%$ within $2.5 \mathrm{~h}$, Fig. 2a). However, $\kappa_{\mathrm{CCN}}$ remained largely unchanged within the experimental uncertainty upon the formation of ABSOA (green and blue markers). Note that $\kappa_{\mathrm{CCN}}$ should be compared at similar SS because $\kappa_{\mathrm{CCN}}$ depended on SS and the SS range changed due to the particle size shift after BVOC addition. Such invariance was also observed when BVOC was added first to form BSOA and then AVOC was added to form ABSOA (Fig. 2b). Therefore, we conclude that BSOA, ASOA, and ABSOA have similar CCN activity.

For BSOA, $\kappa_{\mathrm{CCN}}$ increased with photochemical aging at all SS. For ASOA and ABSOA, $\kappa_{\mathrm{CCN}}$ increased with photochemical aging only at higher SS while $\kappa_{\mathrm{CCN}}$ remained relatively stable at low SS (Fig. S2). The increase of $\kappa_{\mathrm{CCN}}$ with aging is a result of oxidation to form oxygenated compounds with higher affinity for water. At the same time, the volatility of BSOA, ASOA, and ABSOA in these experiments decreased with the $\mathrm{OH}$ dose (Emanuelsson et al., 2013), indicating that these hygroscopic components were at the same time less volatile than the initial aerosol components.

Figure $1 \mathrm{~b}$ shows $\kappa_{\mathrm{CCN}}$ as a function of $\mathrm{O} / \mathrm{C}$. Although the $\mathrm{O} / \mathrm{C}$ of ASOA and ABSOA was generally higher than that of BSOA (Fig. 1b), there is no significant difference between the CCN activity of ASOA, ABSOA, and that of BSOA. This suggests that although ASOA components increased the $\mathrm{O} / \mathrm{C}$ of ABSOA and decreased its volatility (Emanuelsson et al., 2013), it did not enhance its CCN activity. We conclude that the interaction of AVOC with BVOC oxidation products, such as potential oligomerization during the photochemical oxidation does not affect $\mathrm{CCN}$ activity of the resulting ABSOA. Decreasing volatility and invariant $\mathrm{CCN}$ activity at higher $\mathrm{O} / \mathrm{C}$ induced by the presence of ASOA components indicates different effects of oligomerization and photochemistry on volatility and $\mathrm{CCN}$ activity of aerosol. While both oligomerization and photochemical aging reduce the volatility (Emanuelsson et al., 2013), they have counterbalancing effects on $\mathrm{CCN}$ activity. Oligomerization increases the molar volume and decreases the molar concentration of solutes, which results in an increase of water activity and thus the saturation ratio. Therefore, oligomerization reduces $\mathrm{CCN}$ activity, while photochemical aging enhances the $\mathrm{CCN}$ activity by producing more oxygenated compounds via functionalization (Zhao et al., 2015b). As shown in Eq. (A6), $\kappa$ is affected by the molar volume of organics and by the van't Hoff factor (the ratio of the actual concentration of molecules or ions produced when the substance is dissolved to the concentration of the substance if it does not dissociate). Functionalization does not significantly change the molar volume of organics, but it increases the van't Hoff factor due to both its interaction of polar functional groups with water and additional dissociation effects by carboxylic and hydroxyl group (Petters et al., 2009; Tritscher et al., 2011). In this study we
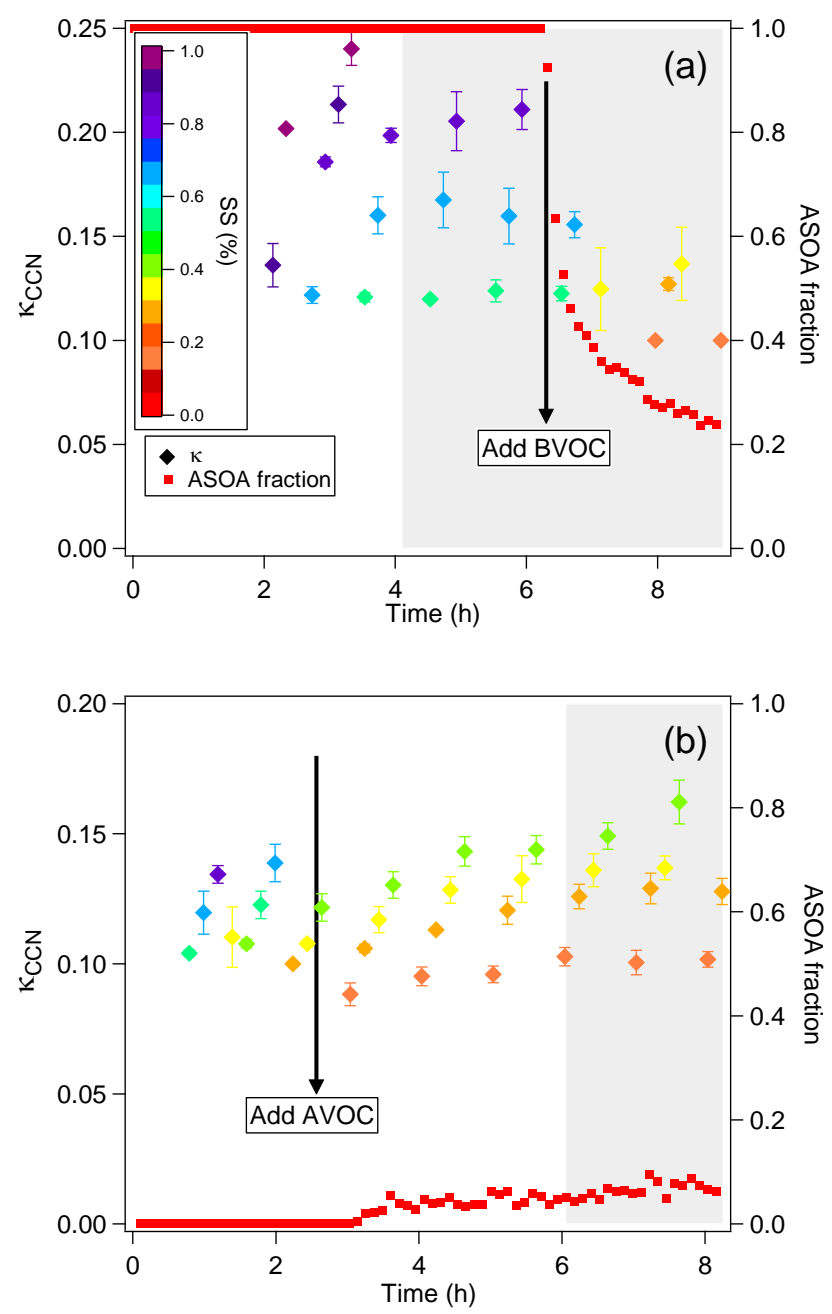

Figure 2. CCN activity of ABSOA from sequential VOC addition at various supersaturations (SS). (a) Toluene was added first and monoterpenes were added $6 \mathrm{~h}$ afterwards as indicated by the vertical arrow. The shaded areas show dark periods. ASOA fraction (red dots, right axis) decreased remarkably upon BVOC addition but $\kappa_{\mathrm{CCN}}$ showed no significant change. (b) Monoterpenes were added first and toluene was added $2.6 \mathrm{~h}$ afterwards as indicated by the vertical arrow. $\kappa_{\mathrm{CCN}}$ showed no significant change upon the addition of AVOC to BSOA. Note that time series of $\kappa_{\mathrm{CCN}}$ should be followed at similar SS because $\kappa_{\mathrm{CCN}}$ depended on SS and the SS range may change due to the particle size change.

did not observe a significant difference in CCN activity between ABSOA and other SOA, indicating that the effects of possible oligomerization on the $\mathrm{CCN}$ activity of ABSOA are likely compensated by the effects of photochemical aging.

For BSOA and ABSOA, $\kappa_{\mathrm{CCN}}$ generally increases with $\mathrm{O} / \mathrm{C}$ at a given SS (Fig. S2). For ASOA, the relationship between $\kappa_{\mathrm{CCN}}$ and $\mathrm{O} / \mathrm{C}$ is not so apparent. The $\kappa_{\mathrm{CCN}}$ values of BSOA (0.11-0.19) are consistent with $\kappa_{\mathrm{CCN}}$ values obtained in previous studies (Massoli et al., 2010; Lambe et al., 2011; Frosch et al., 2011). An increase of $\kappa_{\mathrm{CCN}}$ with $\mathrm{O} / \mathrm{C}$ 
of SOA has been reported by a number of previous studies (Massoli et al., 2010; Lambe et al., 2011). Yet, other studies reported that $\kappa_{\mathrm{CCN}}$ of SOA is largely independent of $\mathrm{O} / \mathrm{C}$ or $f_{44}$, another proxy of the degree of oxidation of organic aerosol (Frosch et al., 2011; Alfarra et al., 2013). The inconclusive results in the literature may be attributed to the differences in reaction conditions including the VOC type and concentration, $\mathrm{NO}_{x}$ concentration, photochemical aging ( $\mathrm{OH}$ dose), and $\mathrm{O} / \mathrm{C}$ range. In this study, the observation that $\kappa_{\mathrm{CCN}}$ is invariant on $\mathrm{O} / \mathrm{C}$ in ASOA may be associated with the relatively high and narrow range of observed O/C for ASOA. Emanuelsson et al. (2013) proposed that first generation products of AVOC (mainly carbonyls) may have higher vapor pressure compared to BVOC products. Therefore, AVOC need a higher $\mathrm{OH}$ dose and more oxidation steps before a significant amount of material starts to condense on the particles. As a result, once SOA started to form, ASOA had already reached a relatively high $\mathrm{O} / \mathrm{C}$ due to aging in the gas phase (Fig. 1b). As a consequence, a further increase of $\mathrm{O} / \mathrm{C}$ in ASOA is likely slower and less pronounced.

Considering all types of SOA investigated here, $\kappa_{\mathrm{CCN}}$ did not correlate with $\mathrm{O} / \mathrm{C}$ here (Fig. 1b), which is in agreement with the findings of Alfarra et al. (2013) that water uptake is independent of $f_{44}$ as a metric of the degree of oxidation for multiple biogenic precursors. This is because $\mathrm{O} / \mathrm{C}$ affects the solubility of the solute but other effects such as molecular weight, surface tension, and density are also important. Massoli et al. (2010) also showed, the correlation between $\kappa_{\mathrm{CCN}}$ derived from $\mathrm{CCN}$ and $\mathrm{O} / \mathrm{C}$ is less significant than in individual systems, when considering all systems together including $\alpha$-pinene, trimethylbenzene, and $\mathrm{m}$-xylene. The relationship between $\kappa_{\mathrm{CCN}}$ and $\mathrm{O} / \mathrm{C}$ was further compared to the parameterization in the study by Rickards et al. (2013) (Fig. S5), which was obtained from their experimental data and a number of literature data and showed very large variability of $\kappa$ vs. $\mathrm{O} / \mathrm{C}$.

For ASOA systems, particle formation was studied for different aromatic precursors at low $\mathrm{NO}_{x}\left(\mathrm{NO}_{x}<1 \mathrm{ppb}\right)$ and high $\mathrm{NO}_{x}$ concentrations (10 ppb of $\mathrm{NO}$ added). The $\mathrm{CCN}$ activity of ASOA from different precursors including toluene, xylene, and benzene was found to be similar. Although $\mathrm{NO}_{x}$ levels affect the overall SOA particle composition and yields ( $\mathrm{Ng}$ et al., 2007a, b; Hildebrandt et al., 2009; Zhang et al., 2014; Presto et al., 2005; Eddingsaas et al., 2012), they had no significant effect on the CCN activity of ASOA comparing the low $\mathrm{NO}_{x}\left(\mathrm{NO}_{x}<1 \mathrm{ppb}\right)$ with high $\mathrm{NO}_{x}$ (10 ppb NO added) condition (Fig. S3). The CCN activity of ASOA generally agreed with the range obtained from a number of previous studies (Massoli et al., 2010; Prenni et al., 2007; Lambe et al., 2011). Similarly, $\mathrm{NO}_{x}$ level has been found to not influence the CCN activity of SOA from $\alpha$-pinene ozonolysis and subsequent photochemical aging (Frosch et al., 2011).

\subsubsection{Droplet growth kinetics}

Droplet growth kinetics was investigated using the method of threshold droplet growth analysis (TDGA), which has been used successfully in many field and laboratory studies (Engelhart et al., 2008; Asa-Awuku et al., 2009, 2010; Bougiatioti et al., 2011). In this method, the droplet growth kinetics was assessed by comparing the droplet sizes from various SOA with that from ammonium sulfate, which is highly hygroscopic and rapidly grows under supersaturated conditions. When two particles are exposed to the same SS, they will grow to droplets of similar size, if their critical SS and the mass transfer of water vapor are similar. In this study, the TDGA method was applied to the size-resolved CCNC data and droplet size was compared for activated particles with $\mathrm{SS}_{\text {crit }}$ equal to the instrument SS (i.e., particles with a size of $D_{\text {crit }}$ ) (Asa-Awuku et al., 2009, 2010; Bougiatioti et al., 2011).

Droplet size as a function of SS for BSOA, ASOA, and ABSOA were compared with that of ammonium sulfate (Fig. 3). The droplet sizes of BSOA, ABSOA, or ASOA are similar to those of ammonium sulfate. This indicates the absence of a kinetic barrier for the water uptake of these SOA during droplet activation. Our study is in agreement with several previous studies showing comparable droplet growth kinetics of SOA from monoterpenes with that of ammonium sulfate (Engelhart et al., 2008; Frosch et al., 2011). For SOA from toluene or xylene, no report on droplet growth kinetics was found in the literature. The droplet growth of aerosol from anthropogenic sources in the field containing both organics and ammonium sulfate has been shown to be slower than that of the pure ammonium sulfate, using a static diffusion cloud condensation chamber (Shantz et al., 2010, 2012). Based on our study, ASOA from common aromatics, does not explain such delay and the observations by Shantz and co-workers must have been caused by other aerosol components (Shantz et al., 2010, 2012).

A recent laboratory study by Loza et al. (2013) suggests limited mixing of different types of SOA components in the particles formed from BSOA precursor $\alpha$-pinene and ASOA precursor toluene added sequentially. In contrast, the study of Hildebrandt et al. (2011) supported the pseudo-ideal mixing of BSOA and ASOA components according to the aerosol mass yield. Based on the droplet growth kinetics of the ABSOA (Fig. 3) observed in this study, no matter whether ASOA and BSOA components are well mixed in the particles, mixing issues did not seem to affect the water uptake of particles in supersaturated conditions. Hence, the kinetics of ABSOA, ASOA, and BSOA activation may be regarded to be similar when cloud activation is considered. 


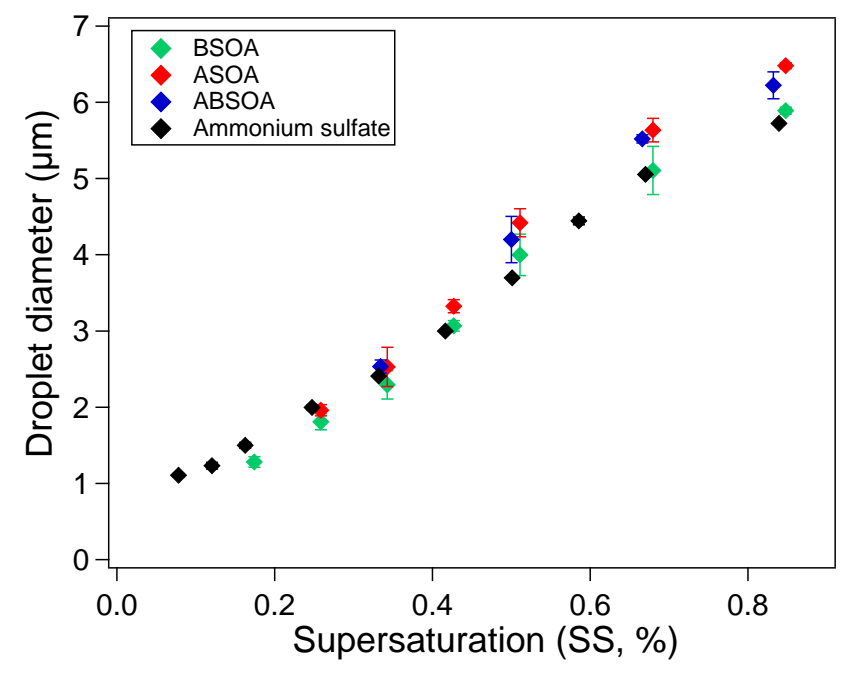

Figure 3. Droplet sizes of BSOA, ASOA, ABSOA, and ammonium sulfate aerosols at various supersaturations (SS). In the CCNC, all SOA particles reached comparable droplet sizes compared to ammonium sulfate.

\subsection{Hygroscopicity of SOA from HTDMA measurement}

Figure 4 shows the hygroscopicity $\left(\kappa_{\mathrm{HTDMA}}\right)$ of BSOA, ASOA, and ABSOA. $\kappa_{\text {HTDMA }}$ of BSOA was between 0.03 and 0.06 , and increased slightly with $\mathrm{OH}$ dose. $\kappa_{\text {HTDMA }}$ of ASOA was around 0.09-0.1, significantly higher than that of BSOA. Subsaturated hygroscopic growth of ASOA and BSOA was obviously different whereas their $\mathrm{CCN}$ activity was basically similar. The influence of the SOA types on the hygroscopic growth is different from their influence on $\mathrm{CCN}$ activity. The comparison between the water uptake in the subsaturated conditions from hygroscopic growth and that in the supersaturated conditions from CCN activity is discussed in the Sect. 3.3. $\kappa_{\text {HTDMA }}$ of ASOA did not change much with the $\mathrm{OH}$ dose and $\kappa_{\text {HTDMA }}$ of ASOA from different aromatic precursors (toluene, xylene, and benzene) were similar (nos. A1, 2, 4, 5 in Fig. 4).

The higher $\kappa_{\text {HTDMA }}$ of ASOA can be related to the chemical composition represented by $\mathrm{O} / \mathrm{C}$. The $\mathrm{O} / \mathrm{C}$ of BSOA was about $0.3-0.5$, distinctively lower than that of ASOA (0.7$0.8)$. $\mathrm{O} / \mathrm{C}$ has been found to correlate with $\kappa_{\text {HTDMA }}$ for various SOA systems (Jimenez et al., 2009; Massoli et al., 2010; Duplissy et al., 2008, 2011; Lambe et al., 2011). The same arguments as for CCN activity apply here. ASOA reached much higher $\mathrm{O} / \mathrm{C}$ at the same $\mathrm{OH}$ dose compared to BSOA (Fig. S4) (Emanuelsson et al., 2013) because first generation products of AVOC have a smaller carbon number and higher vapor pressure compared to BVOC. Thus, first generation products of AVOC need more oxidation steps before starting to condense significantly on particles as discussed in Sect. 3.1. In addition, constituents of aromatic ASOA generally have lower molecular weights than BSOA molecules
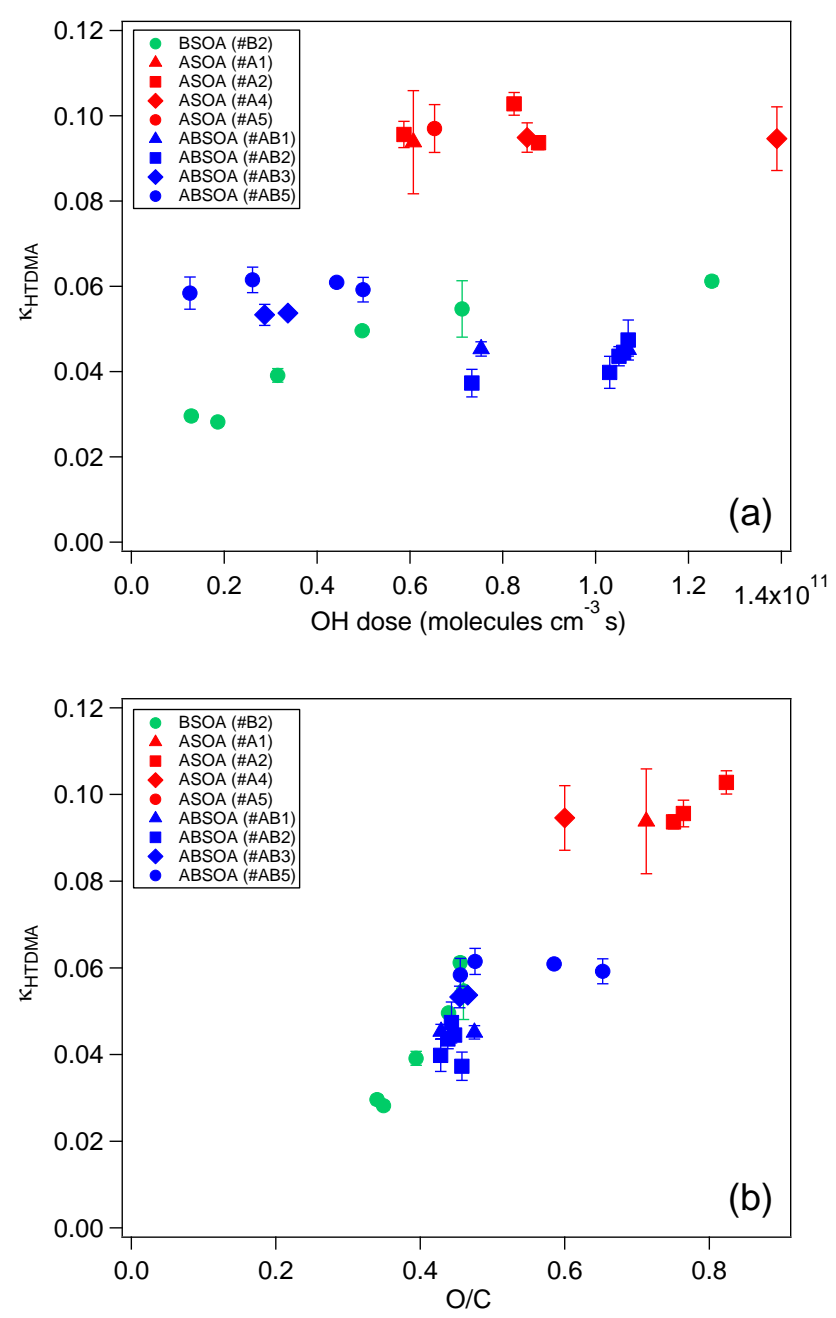

Figure 4. $\kappa_{\mathrm{HTDMA}}$ for BSOA, ASOA, and ABSOA as a function of $\mathrm{OH}$ dose (a) and $\mathrm{O} / \mathrm{C}$ of aerosol (b). ASOA had a distinctively higher $\kappa_{\text {HTDMA }}$ and $\mathrm{O} / \mathrm{C}$ than BSOA.

here. We can expect that ASOA components have on average a lower molar volume and thus ASOA has higher $\kappa_{\text {HTDMA }}$ assuming all other parameters are the same for ASOA and BSOA (cf. Appendix A), since $\kappa$ is by definition the ratio of the molar volume of water to the average molar volume of the solute.

The $\kappa_{\text {HTDMA }}$ observed for ABSOA formed with AVOC and $\mathrm{BVOC}$ added in various orders were in the range 0.030.06 , close to or slightly higher than the $\kappa_{\mathrm{HTDMA}}$ of BSOA. The observed $\mathrm{O} / \mathrm{C}$ range of $\mathrm{ABSOA}$ was slightly higher than the O/C range of BSOA, but partly overlapping. Since ASOA had much higher $\kappa_{\text {HTDMA }}$ than BSOA, ASOA enhanced the $\kappa_{\mathrm{HTDMA}}$ of ABSOA and the extent of enhancement depended on its fraction.

The enhanced $\kappa_{\text {HTDMA }}$ due to ASOA fraction was also reflected clearly in the ABSOA experiments when AVOC and BVOC were sequentially added. In the experiment when ASOA was formed first, the SOA showed higher $\kappa_{\mathrm{HTDMA}}$, 
around 0.09 (Fig. 5a). When BVOC was added to the system, ASOA was converted to ABSOA with a significant BSOA fraction (e.g., $70 \%$ within $2.5 \mathrm{~h}$ ) and $\kappa_{\text {HTDMA }}$ decreased from 0.09 to 0.04 with the formation of the BSOA components. Meanwhile the degree of oxidation of ABSOA decreased significantly as indicated by the decrease of $f_{44}$ (from 0.23 to 0.1). For the experiments when AVOC was added to BSOA system, an effect was recognizable; however, $\kappa_{\text {HTDMA }}$ only increased slightly (Fig. 5 b). This was because the reaction of aromatics with $\mathrm{OH}$ and SOA formation was slow and the fraction of ASOA did not exceed $10 \%$. Accordingly, only a slight increase of $f_{44}$ was observed (from 0.10 to 0.12 ) even with concurrent aging, consistent with the minor effects of the ASOA component on the chemical composition of ABSOA due to its low fraction.

Since ASOA has higher $\kappa_{\text {HTDMA }}$, mixing of ASOA with BSOA may directly enhance $\kappa_{\text {HTDMA }}$ due to a simple linear mixing. In order to understand the role of ASOA components in enhancing $\kappa_{\text {HTDMA }}$ of ABSOA, $\kappa_{\text {HTDMA }}$ was also examined as a function of the ASOA fraction (as shown in Fig. 6). In the ABSOA experiment, two main factors affect the hygroscopicity: aging of the BSOA components and increasing fraction of ASOA components. Therefore, the $\mathrm{OH}$ dose is examined to account for the effect of aging. In Fig. 6, the dashed lines connect the $\kappa_{\text {HTDMA }}$ of pure BSOA and pure ASOA of the same $\mathrm{OH}$ dose at a series of $\mathrm{OH}$ doses varying from fresh to aged SOA. Such a graph can help to detect whether the $\kappa_{\text {HTDMA }}$ of ABSOA can be described by a simple linear mixing of the $\kappa_{\mathrm{HTDMA}}$ of BSOA and ASOA components with respect to their volume fraction or where nonlinear response of $\kappa_{\mathrm{HTDMA}}$ is effective. For each $\mathrm{OH}$ dose, a dashed line connects pure BSOA and pure ASOA at the given $\mathrm{OH}$ dose (represented by the size of marker). This line defines the expected $\kappa_{\text {HTDMA }}$ range of ABSOA with varying ASOA fraction at given $\mathrm{OH}$ dose. If the $\kappa_{\mathrm{HTDMA}}$ of ABSOA can be described by a linear combination of the $\kappa_{\text {HTDMA }}$ of pure ASOA and BSOA components in respect of their volume fraction, the $\kappa_{\mathrm{HTDMA}}$ data point should be on the line corresponding to the given $\mathrm{OH}$ dose of that data point and should increase with ASOA fraction along the line due to the higher $\kappa_{\text {HTDMA }}$ of ASOA. If a succession of points from one experiment cross dashed lines (i.e., points beyond the line corresponding to the $\mathrm{OH}$ dose of those points), it would indicate $\kappa_{\text {HTDMA }}$ cannot be explained by a linear combination.

For ABSOA, several cases with non-linear effects were observed. For ABSOA in experiment no. AB1 and no. AB2 where AVOC was added first, $\kappa_{\text {HTDMA }}$ was significantly lower than the values from the linear combination of pure ASOA and BSOA components (much below the lines corresponding to the $\mathrm{OH}$ doses of the data points). For $\mathrm{AB}$ SOA in experiment no. AB5 when AVOC and BVOC were added together, $\kappa_{\text {HTDMA }}$ did not change significantly in spite of a significant increase of ASOA fraction. In the beginning, $\kappa_{\text {HTDMA }}$ of ABSOA was higher than the value from a linear combination, whereas in the end, $\kappa_{\text {HTDMA }}$ was lower than
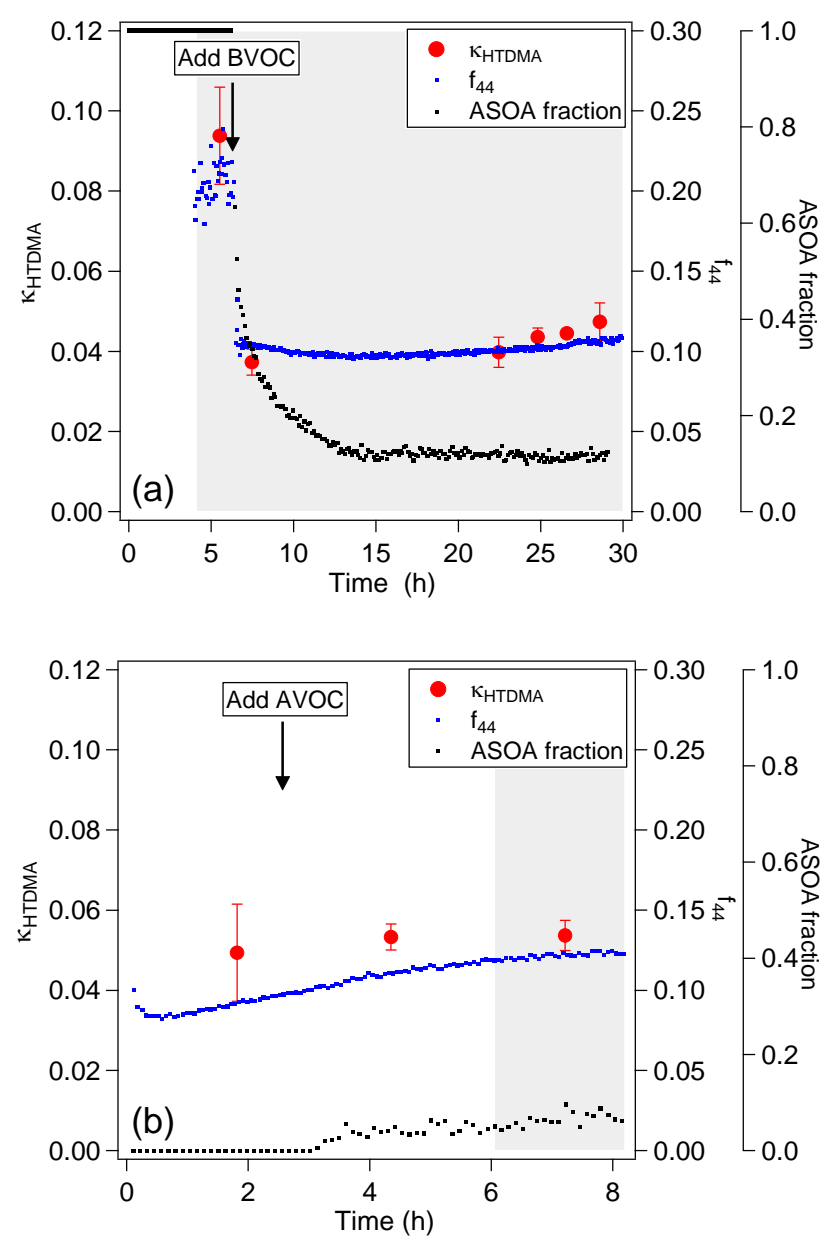

Figure 5. $\kappa_{\text {HTDMA }}$ of ABSOA from experiments when AVOC and BVOC were added sequentially (same experiments as in Fig. 2). (a) Toluene was added first and the monoterpenes were added $6 \mathrm{~h}$ afterwards as indicated by the vertical arrow. The shaded areas indicate the dark periods. $\kappa_{\text {HTDMA }}$ decreased significantly with the decrease of ASOA fraction due to the addition of BVOC. At the same time, $f_{44}$ decreased distinctively. (b) Monoterpenes were added first and toluene was added $2.6 \mathrm{~h}$ afterwards as indicated by the vertical arrow. $\kappa_{\text {HTDMA }}$ increased slightly as only a minor fraction $(<10 \%)$ of ASOA was formed. At the same time, $f_{44}$ also increased slightly.

the value from a linear combination of pure systems. These cases indicate that the observed $\kappa_{\text {HTDMA }}$ of ABSOA cannot be explained by a simple linear combination of pure ASOA and BSOA systems. There seems to be some additional effects such as oligomerization, which altered the chemical composition of ABSOA and thus affected $\kappa_{\text {HTDMA. More- }}$ over, for the ABSOA in experiment no. AB5, $\kappa_{\text {HTDMA }}$ remained largely unchanged in spite of continuous oxidation and increase of ASOA fraction, both enhancing hygroscopicity. This further indicates that the possible oligomerization, which should decrease the Raoult term and thus hygroscopicity, compensates the effect of photochemical aging, which 


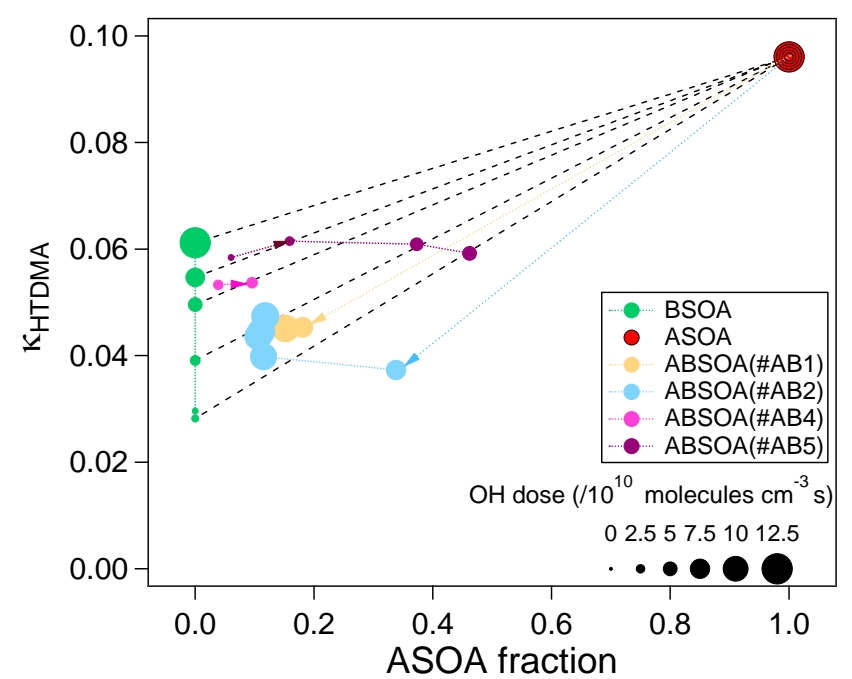

Figure 6. $\kappa_{\text {HTDMA }}$ of ABSOA as a function of ASOA fraction. The size of the marker denotes the $\mathrm{OH}$ dose. For ASOA, $\kappa_{\text {HTDMA }}$ is largely independent of $\mathrm{OH}$ dose and the average value was used, shown as the same point for different $\mathrm{OH}$ dose. The dashed lines connecting the pure BSOA and ASOA of the same OH doses stand for the linear combination of the $\kappa_{\mathrm{HTDMA}}$ of pure BSOA and pure ASOA at that given $\mathrm{OH}$ dose. A data point beyond the line corresponding to the $\mathrm{OH}$ dose of that point indicates a non-linear effect. The cases of non-linear effect can be found for ABSOA no. AB1, no. AB2, and no. AB5. The dotted lines with arrow of ABSOA show the time order of data points.

enhances hygroscopicity, consistent with the discussion in Sect. 3.1.

Morphological effects can also play a role. If the ASOA and BSOA components were not well mixed in the aerosol particles in the experiments with sequential VOC additions, there would be more BSOA components on SOA particle surface in experiments no. AB1 and no. AB2. This could affect the $\kappa_{\text {HTDMA }}$ and contribute to the non-linear effect. But this cannot explain the non-linear effect in the experiment with VOCs added simultaneously. In addition, if ABSOA forms a glassy state, the lower diffusivity in the particle may hinder water uptake thus decreasing $\kappa_{\mathrm{HTDMA}}$. Although similar growth kinetics of SOA to $\left(\mathrm{NH}_{4}\right)_{2} \mathrm{SO}_{4}$ was observed in supersaturated conditions, in subsaturated conditions the water diffusivity in the particle may be limited thus limiting water uptake.

The ABSOA filter samples from experiment no. AB4 and no. AB6 were extracted and analyzed for oligomers. We observed the oligomer formation in these samples (Fig. S6). Oligomer in SOA has been found by a number of studies (Gao et al., 2004; Noziere et al., 2015; Tolocka et al., 2004; Kalberer et al., 2004; Kourtchev et al., 2014, 2015). Small multi-functional products from aromatics oxidation (Hamilton et al., 2005; Jenkin et al., 2003; Johnson et al., 2005) may promote oligomerization between ASOA and BSOA components. But we did not find indications that ABSOA contained more dimers compared to BSOA. This can be attributed to the low ASOA fraction $\leq 5 \%$ in experiments no. AB4 and no. AB6 (estimated using the method as in Emanuelsson et al., 2013). The low ASOA fraction was caused by the low $\mathrm{OH}$ concentration and low chemical turnover of the aromatics in these experiments because high concentrations of VOC were used in order to generate enough particle mass for optical measurement (Flores et al., 2014). The low fraction of ASOA resulted in little oligomer formation by the interaction between the ASOA components and BSOA components. In the future experiments, conditions that can form comparable fractions of both ASOA and BSOA and thus are favorable to ASOA and BSOA interaction such as oligomerization are preferred. Therefore, relatively higher AVOC concentration and higher $\mathrm{OH}$ concentration (as in experiment no. AB5) are desirable.

\subsection{Closure between the hygroscopicity parameter from CCN and HTDMA}

The hygroscopicity parameter $\kappa$ was obtained from CCN and HTDMA measurements in supersaturated and subsaturated conditions, respectively. For all SOA types studied here, there is a significant gap between $\kappa_{\text {HTDMA }}$ and $\kappa_{\mathrm{CCN}}$. $\kappa_{\mathrm{HTDMA}}$ was significantly lower than $\kappa_{\mathrm{CCN}}$ with $\kappa_{\mathrm{HTDMA}} / \kappa_{\mathrm{CCN}}$ around $0.3-0.7$ (Fig. 7). The ratio of $\kappa_{\mathrm{HTDMA}} / \kappa_{\mathrm{CCN}}$ for BSOA and ABSOA was lower than that of ASOA, which is closer to 1 . This means that there is a smaller gap between $\kappa_{\mathrm{HTDMA}}$ and $\kappa_{\mathrm{CCN}}$ for ASOA compared to BSOA and ABSOA.

The closure between $\kappa_{\mathrm{CCN}}$ and $\kappa_{\mathrm{HTDMA}}$ of SOA has been studied and discussed by a number of previous studies with varying results (Dusek et al., 2011; Alfarra et al., 2013; Good et al., 2010; Duplissy et al., 2008; Juranyi et al., 2009; Prenni et al., 2007; Massoli et al., 2010; Hansen et al., 2015; Wex et al., 2009; Whitehead et al., 2014). The discrepancy between $\kappa_{\mathrm{CCN}}$ and $\kappa_{\mathrm{HTDMA}}$ found here can be attributed to several possible reasons as discussed in the literature (Prenni et al., 2007; Massoli et al., 2010; Frosch et al., 2011; Good et al., 2010; Alfarra et al., 2013; Wex et al., 2009; Whitehead et al., 2014; Petters et al., 2009; Dusek et al., 2011). An important reason is the presence of slightly soluble compounds. These compounds only dissolve partly in the subsaturated condition while they can dissolve completely in the supersaturated conditions due to more water available. Therefore, $\kappa$ is underestimated to varied extent in the subsaturated condition. ASOA components here seemed to have higher solubility compared to BSOA components, and thus the gap between $\kappa_{\mathrm{CCN}}$ and $\kappa_{\text {HTDMA }}$ was smaller than that of BSOA.

Surface tension can also play a role in this discrepancy. $\kappa$ was calculated using the surface tension of pure water $\left(0.073 \mathrm{~N} \mathrm{~m}^{-1}\right)$. If the surface tension of the droplets is lower than that of water, $\kappa$ would be overestimated. While $\kappa_{\mathrm{HTDMA}}$ is not so sensitive to the change of surface tension, $\kappa_{\mathrm{CCN}}$ is more sensitive to surface tension at the point of activa- 


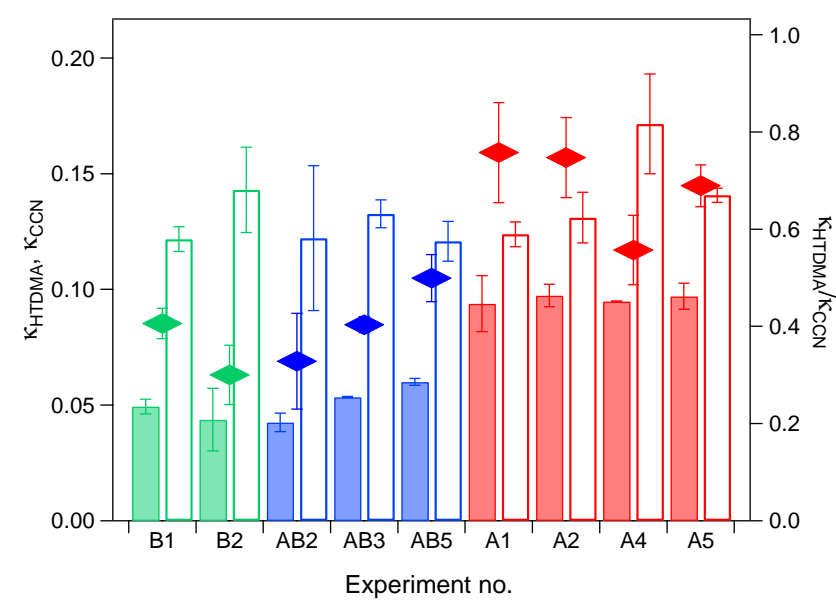

Figure 7. Comparison of $\kappa_{\mathrm{HTDMA}}$ and $\kappa_{\mathrm{CCN}}$ from HTDMA and $\mathrm{CCN}$ measurements for BSOA, ASOA, and ABSOA. The solid bar denotes the $\kappa_{\text {HTDMA }}$ and the open bar denotes $\kappa_{\mathrm{CCN}}$ (left axis). The diamond denotes the ratio of $\kappa_{\mathrm{HTDMA}}$ to $\kappa_{\mathrm{CCN}}$ (right axis). The green, blue, and red colors indicate the BSOA, ABSOA, and ASOA, respectively. For all SOA here, there was a discrepancy between $\kappa_{\mathrm{HTDMA}}$ and $\kappa_{\mathrm{CCN}}$. For ASOA, the gap between $\kappa_{H T D M A}$ and $\kappa_{\mathrm{CCN}}\left(\right.$ low $\left.\kappa_{\mathrm{HTDMA}} / \kappa_{\mathrm{CCN}}\right)$ was smaller compared to BSOA.

tion according to the Köhler equation (Petters and Kreidenweis, 2007). The surface tension under the subsaturated conditions is assumed to be lower than that under the supersaturated conditions due to the more concentrated organics in the droplets under the subsaturated condition (Prisle et al., 2008). If the surface tension effect for BSOA would be larger than for ASOA, i.e., lower surface tension in supersaturated conditions, this would lead to a higher $\kappa_{\mathrm{CCN}}$ for BSOA. While the surface tension effect in subsaturated conditions is small, i.e., $\kappa_{\mathrm{HTDMA}}$ is relatively constant, higher $\kappa_{\mathrm{CCN}}$ of BSOA results in a larger discrepancy between $\kappa_{\mathrm{HTDMA}}$ and $\kappa_{\mathrm{CCN}}$. However, surface active organics can be enriched at the surface to such a high extent that the Raoult term is significantly diminished (Prisle et al., 2008). This difference can compensate the overestimation by using the surface tension of water and the compensating effects make using surface tension of water be a reasonable choice.

Furthermore, the $\kappa$-Köhler model does not account explicitly for changes in non-ideality of a solution as a function of saturation ratio, i.e., water activity. Instead, $\kappa$ might be not constant through the whole range of water activity (Petters and Kreidenweis, 2007). In addition, different aerosol behaviors such as evaporation and condensation of organics in HTDMA and CCN instrument and limited diffusivity of water in case of glassy particles can contribute to the discrepancy (Whitehead et al., 2014; Asa-Awuku et al., 2009; Irwin et al., 2010; Topping and McFiggans, 2012; Topping et al., 2013; Duplissy et al., 2009).

\section{Conclusions and implications}

We investigated the droplet activation, droplet growth kinetics and hygroscopicity of the BSOA, ASOA, and ABSOA formed from monoterpenes and aromatics used as representative BVOC and AVOC.

We found that BSOA, ASOA, and ABSOA had similar CCN activity although ASOA had a higher O/C. Adding BVOC after ASOA formation, or adding AVOC after BSOA formation did not significantly change the CCN activity of SOA. The similar CCN activity of BSOA, ASOA, and ABSOA suggests that ASOA components and the interaction of ASOA with BSOA did not significantly change the CCN activity of SOA. This was likely due to compensating effects of potential oligomerization (reducing effect) and photochemical aging (enhancing effect) on CCN activity.

$\kappa_{\mathrm{CCN}}$ generally increased slightly with photochemical aging, using $\mathrm{OH}$ dose as a proxy of photochemical aging and increased with $\mathrm{O} / \mathrm{C}$ of aerosol for individual reaction systems. But when taking all the SOA types into account, $\kappa_{\mathrm{CCN}}$ did not correlate with $\mathrm{O} / \mathrm{C}$.

Analysis of the droplet growth kinetics shows that the droplet sizes from BSOA, ASOA, and ABSOA in supersaturated conditions were similar to those obtained with ammonium sulfate, indicating that none of these SOA has a kinetic barrier for water uptake. The fast water uptake of ASOA indicates that ASOA formed by aromatic precursors is not responsible for the droplet growth delay found in field studies (Shantz et al., 2010, 2012). This finding also suggests that potentially limited mixing between BSOA and ASOA reported in the literature does not hinder the water uptake in supersaturated conditions.

In contrast to $\mathrm{CCN}$ activity, the hygroscopicity of ASOA was distinctively higher than that of BSOA. The higher hygroscopicity was related to the higher $\mathrm{O} / \mathrm{C}$ of ASOA compared to BSOA. Therefore, the ASOA component in ABSOA enhanced the hygroscopicity of aerosol and the extent depended on the ASOA fraction. Adding BVOC to ASOA or AVOC to BSOA changed the aerosol hygroscopicity, which was consistent with co-occurring changes in the ASOA fraction and the degree of oxidation of the aerosol represented by $f_{44}$. However, the hygroscopicity of ABSOA cannot be described by a linear combination of pure BSOA and ASOA systems. This indicates that additional processes such as oligomerization suppressed the hygroscopicity, which is in agreement with the interpretations for $\mathrm{CCN}$ activity.

Comparing hygroscopicity parameter $\kappa$ obtained from CCN and HTDMA measurements shows a discrepancy between $\kappa$ from the two methods. $\kappa_{\text {HTDMA }}$ was significantly lower than $\kappa_{\mathrm{CCN}}$ for all SOA types studied here, by $30-70 \%$. This discrepancy could not be resolved but can be attributed to the presence of slightly soluble materials, possible surface tension effect, or non-ideality of solutions and different behaviors of aerosol in the instruments. Better closure, between HTDMA and CCN, was found for ASOA than for BSOA and 
ABSOA. ASOA seemed to have higher solubility in the subsaturated condition and/or lower surface tension at the activation point compared to BSOA.

This study has important implications for assessing the impact of SOA formed by the interaction of biogenic VOC with anthropogenic $\mathrm{VOC}$ emissions on the radiative forcing and climate. Since the interaction of AVOC with BVOC reduces the volatility (Emanuelsson et al., 2013), it prolongs particle persistence, which further enhances the particle concentration. Yet, based on this study, the CCN activity is not significantly affected. Therefore, models to assess the climatic effects of SOA formed through the interaction of biogenic VOC with anthropogenic VOC emissions could use single series of hygroscopicity parameter $\kappa_{\mathrm{CCN}}$ for BSOA, ASOA, and ABSOA to predict $\mathrm{CCN}$ concentration. However, significant mixing of ASOA and BSOA components can change the hygroscopic growth factor of the particles, which further affects the optical properties of SOA.

Comparing emission rates of aromatic compounds and isoprenoids (Lamarque et al., 2010; Guenther et al., 2012) and considering the turnover rates with $\mathrm{OH}$ and $\mathrm{O}_{3}$ suggest that ABSOA should be dominated by BSOA components in most cases, as in most of our experiments. Thus, globally droplet activation and hygroscopic growth may be determined by BSOA. On the regional scale, when an air mass from regions influenced by anthropogenic emissions (e.g., an urban region) transports to regions influenced by biogenic emissions (e.g., a forest region), the physicochemical properties of the mixed SOA formed will likely shift to be BSOAdominated due to the fast turnover of BVOC, i.e., decreasing hygroscopic growth compared with ASOA. In contrast, when an air mass from regions influenced by biogenic emissions transports to regions with anthropogenic emissions, the SOA properties will likely remain those of BSOA due to the slow turnover of AVOC.

\section{Appendix A: Equations related to $\kappa$-Köhler theory}

Based on $\kappa$-Köhler theory (Petters and Kreidenweis, 2007), the following equations are tenable:

$$
\begin{aligned}
& \frac{1}{a_{\mathrm{w}}}=1+\kappa \frac{V_{\mathrm{s}}}{V_{\mathrm{w}}}, \\
& \frac{1}{a_{\mathrm{w}}}=1+i \frac{n_{\mathrm{s}}}{n_{\mathrm{w}}},
\end{aligned}
$$

where $a_{\mathrm{W}}$ is water activity, and $V_{\mathrm{s}}$ and $V_{\mathrm{w}}$ are the volume of solute and water, respectively. $n_{\mathrm{s}}$ and $n_{\mathrm{w}}$ are the amount of solute and water in moles, respectively. I is the van't Hoff factor. $i$ is the ratio of the measured value of a colligative property to the expected value if the solute is a nonelectrolyte (Petrucci and Herring, 2007; McDonald, 1953; Low, 1969). It is the ratio of the actual concentration of molecules or ions produced when a substance is dissolved to the concentration of the substance if it does not dissociate.
From Eq. (A1) and Eq. (A2) one can get

$\kappa=i \frac{V_{\mathrm{w}} / n_{\mathrm{w}}}{V_{\mathrm{s}} / n_{\mathrm{s}}}$.

In addition, the amount of water and solute is described by

$n_{\mathrm{w}}=V_{\mathrm{w}} \rho_{\mathrm{w}} / M_{\mathrm{w}}$,

$n_{\mathrm{s}}=V_{\mathrm{s}} \rho_{\mathrm{s}} / M_{\mathrm{s}}$.

$\rho_{\mathrm{S}}$ and $\rho_{\mathrm{W}}$ are the density of solute and water, and $M_{\mathrm{S}}$ and $M_{\mathrm{W}}$ are the molecular weight of solute and water, respectively.

Substituting Eqs. (A4) and (A5) into Eq. (A3) yields

$\kappa=i \frac{M_{\mathrm{w}} / \rho_{\mathrm{w}}}{M_{\mathrm{s}} / \rho_{\mathrm{s}}}$.

Assuming $i$ is constant, $\kappa$ is the ratio of molar volume of water to the average molar volume of the solute. Thus, a compound with lower molecular weight at similar density has lower molar volume and tends to have higher $\kappa$ provided that other factors are constant.

The Supplement related to this article is available online at doi:10.5194/acp-16-1105-2016-supplement.

Acknowledgements. This study was supported by the EUROCHAMP2 (Integration of European Simulation Chambers for Investigating Atmospheric Processes) - EC 7th framework. We thank the SAPHIR team, especially Franz Rohrer, Rolf Häseler, Birger Bohn, Martin Kaminski, Sascha Nehr, Sebastian Schmitt, Anna Lutz, Eva Emanuelsson, and Ismail-Hakki Acir for providing helpful data and supporting our measurements. Marianne Glasius thanks the funding support from NordForsk through the Nordic Centre of Excellence Cryosphere-Atmosphere Interactions in a Changing Arctic Climate (CRAICC) and the VILLUM Foundation. We thank two anonymous reviewers for the constructive comments.

The article processing charges for this open-access publication were covered by a Research Centre of the Helmholtz Association.

Edited by: H. Su

\section{References}

Aiken, A. C., DeCarlo, P. F., and Jimenez, J. L.: Elemental analysis of organic species with electron ionization highresolution mass spectrometry, Anal. Chem., 79, 8350-8358, doi:10.1021/ac071150w, 2007.

Aiken, A. C., Decarlo, P. F., Kroll, J. H., Worsnop, D. R., Huffman, J. A., Docherty, K. S., Ulbrich, I. M., Mohr, C., Kimmel, J. R., Sueper, D., Sun, Y., Zhang, Q., Trimborn, A., Northway, M., Ziemann, P. J., Canagaratna, M. R., Onasch, T. B., Alfarra, M. R., Prevot, A. S. H., Dommen, J., Duplissy, J., Metzger, A., Baltensperger, U., and Jimenez, J. L.: O/C and OM/OC ratios of primary, secondary, and ambient organic aerosols with highresolution time-of-flight aerosol mass spectrometry, Environ. Sci. Technol., 42, 4478-4485, doi:10.1021/es703009q, 2008. 
Alfarra, M. R., Good, N., Wyche, K. P., Hamilton, J. F., Monks, P. S., Lewis, A. C., and McFiggans, G.: Water uptake is independent of the inferred composition of secondary aerosols derived from multiple biogenic VOCs, Atmos. Chem. Phys., 13, 1176911789, doi:10.5194/acp-13-11769-2013, 2013.

Allan, J. D., Delia, A. E., Coe, H., Bower, K. N., Alfarra, M. R., Jimenez, J. L., Middlebrook, A. M., Drewnick, F., Onasch, T. B., Canagaratna, M. R., Jayne, J. T., and Worsnop, D. R.: A generalised method for the extraction of chemically resolved mass spectra from aerodyne aerosol mass spectrometer data, J. Aerosol Sci., 35, 909-922, doi:10.1016/j.jaerosci.2004.02.007, 2004.

Apel, E. C., Brauers, T., Koppmann, R., Bandowe, B., Bossmeyer, J., Holzke, C., Tillmann, R., Wahner, A., Wegener, R., Brunner, A., Jocher, M., Ruuskanen, T., Spirig, C., Steigner, D., Steinbrecher, R., Alvarez, E. G., Muller, K., Burrows, J. P., Schade, G., Solomon, S. J., Ladstatter-Weissenmayer, A., Simmonds, P., Young, D., Hopkins, J. R., Lewis, A. C., Legreid, G., Reimann, S., Hansel, A., Wisthaler, A., Blake, R. S., Ellis, A. M., Monks, P. S., and Wyche, K. P.: Intercomparison of oxygenated volatile organic compound measurements at the SAPHIR atmosphere simulation chamber, J. Geophys. Res.-Atmos., 113, D20307, doi:10.1029/2008jd009865, 2008.

Asa-Awuku, A., Sullivan, A. P., Hennigan, C. J., Weber, R. J., and Nenes, A.: Investigation of molar volume and surfactant characteristics of water-soluble organic compounds in biomass burning aerosol, Atmos. Chem. Phys., 8, 799-812, doi:10.5194/acp8-799-2008, 2008.

Asa-Awuku, A., Engelhart, G. J., Lee, B. H., Pandis, S. N., and Nenes, A.: Relating CCN activity, volatility, and droplet growth kinetics of $\beta$-caryophyllene secondary organic aerosol, Atmos. Chem. Phys., 9, 795-812, doi:10.5194/acp-9-795-2009, 2009.

Asa-Awuku, A., Nenes, A., Gao, S., Flagan, R. C., and Seinfeld, J. H.: Water-soluble SOA from Alkene ozonolysis: composition and droplet activation kinetics inferences from analysis of $\mathrm{CCN}$ activity, Atmos. Chem. Phys., 10, 1585-1597, doi:10.5194/acp10-1585-2010, 2010.

Bohn, B. and Zilken, H.: Model-aided radiometric determination of photolysis frequencies in a sunlit atmosphere simulation chamber, Atmos. Chem. Phys., 5, 191-206, doi:10.5194/acp-5-1912005, 2005.

Bohn, B., Rohrer, F., Brauers, T., and Wahner, A.: Actinometric measurements of $\mathrm{NO}_{2}$ photolysis frequencies in the atmosphere simulation chamber SAPHIR, Atmos. Chem. Phys., 5, 493-503, doi:10.5194/acp-5-493-2005, 2005.

Bougiatioti, A., Nenes, A., Fountoukis, C., Kalivitis, N., Pandis, S. N., and Mihalopoulos, N.: Size-resolved CCN distributions and activation kinetics of aged continental and marine aerosol, Atmos. Chem. Phys., 11, 8791-8808, doi:10.5194/acp-11-87912011, 2011.

Buchholz, A.: Secondary organic aerosols: Chemical aging, hygroscopicity, and cloud droplet activation, Ph.D., Department of Chemistry, University of Cologne, Cologne, 2010.

Chhabra, P. S., Ng, N. L., Canagaratna, M. R., Corrigan, A. L., Russell, L. M., Worsnop, D. R., Flagan, R. C., and Seinfeld, J. H.: Elemental composition and oxidation of chamber organic aerosol, Atmos. Chem. Phys., 11, 8827-8845, doi:10.5194/acp-11-88272011, 2011.

de Gouw, J. A., Middlebrook, A. M., Warneke, C., Goldan, P. D., Kuster, W. C., Roberts, J. M., Fehsenfeld, F. C., Worsnop,
D. R., Canagaratna, M. R., Pszenny, A. A. P., Keene, W. C., Marchewka, M., Bertman, S. B., and Bates, T. S.: Budget of organic carbon in a polluted atmosphere: Results from the New England Air Quality Study in 2002, J. Geophys. Res.-Atmos., 110, D16305, doi:10.1029/2004jd005623, 2005.

de Gouw, J. A., Brock, C. A., Atlas, E. L., Bates, T. S., Fehsenfeld, F. C., Goldan, P. D., Holloway, J. S., Kuster, W. C., Lerner, B. M., Matthew, B. M., Middlebrook, A. M., Onasch, T. B., Peltier, R. E., Quinn, P. K., Senff, C. J., Stohl, A., Sullivan, A. P., Trainer, M., Warneke, C., Weber, R. J., and Williams, E. J.: Sources of particulate matter in the northeastern United States in summer: 1. Direct emissions and secondary formation of organic matter in urban plumes, J. Geophys. Res.-Atmos., 113, D08301, doi:10.1029/2007jd009243, 2008.

Donahue, N. M., Henry, K. M., Mentel, T. F., Kiendler-Scharr, A., Spindler, C., Bohn, B., Brauers, T., Dorn, H. P., Fuchs, H., Tillmann, R., Wahner, A., Saathoff, H., Naumann, K. H., Mohler, O., Leisner, T., Muller, L., Reinnig, M. C., Hoffmann, T., Salo, K., Hallquist, M., Frosch, M., Bilde, M., Tritscher, T., Barmet, P., Praplan, A. P., DeCarlo, P. F., Dommen, J., Prevot, A. S. H., and Baltensperger, U.: Aging of biogenic secondary organic aerosol via gas-phase $\mathrm{OH}$ radical reactions, P. Natl. Acad. Sci. USA, 109, 13503-13508, doi:10.1073/pnas.1115186109, 2012.

Duplissy, J., Gysel, M., Alfarra, M. R., Dommen, J., Metzger, A., Prevot, A. S. H., Weingartner, E., Laaksonen, A., Raatikainen, T., Good, N., Turner, S. F., McFiggans, G., and Baltensperger, U.: Cloud forming potential of secondary organic aerosol under near atmospheric conditions, Geophys. Res. Lett., 35, L03818, doi:10.1029/2007g1031075, 2008.

Duplissy, J., Gysel, M., Sjogren, S., Meyer, N., Good, N., Kammermann, L., Michaud, V., Weigel, R., Martins dos Santos, S., Gruening, C., Villani, P., Laj, P., Sellegri, K., Metzger, A., McFiggans, G. B., Wehrle, G., Richter, R., Dommen, J., Ristovski, Z., Baltensperger, U., and Weingartner, E.: Intercomparison study of six HTDMAs: results and recommendations, Atmos. Meas. Tech., 2, 363-378, doi:10.5194/amt-2-363-2009, 2009.

Duplissy, J., DeCarlo, P. F., Dommen, J., Alfarra, M. R., Metzger, A., Barmpadimos, I., Prevot, A. S. H., Weingartner, E., Tritscher, T., Gysel, M., Aiken, A. C., Jimenez, J. L., Canagaratna, M R., Worsnop, D. R., Collins, D. R., Tomlinson, J., and Baltensperger, U.: Relating hygroscopicity and composition of organic aerosol particulate matter, Atmos. Chem. Phys., 11, 11551165, doi:10.5194/acp-11-1155-2011, 2011.

Dusek, U., Frank, G. P., Massling, A., Zeromskiene, K., Iinuma, Y., Schmid, O., Helas, G., Hennig, T., Wiedensohler, A., and Andreae, M. O.: Water uptake by biomass burning aerosol at suband supersaturated conditions: closure studies and implications for the role of organics, Atmos. Chem. Phys., 11, 9519-9532, doi:10.5194/acp-11-9519-2011, 2011.

Eddingsaas, N. C., Loza, C. L., Yee, L. D., Chan, M., Schilling, K. A., Chhabra, P. S., Seinfeld, J. H., and Wennberg, P. O.: $\alpha$-pinene photooxidation under controlled chemical conditions - Part 2: SOA yield and composition in low- and high- $\mathrm{NO}_{x}$ environments, Atmos. Chem. Phys., 12, 7413-7427, doi:10.5194/acp-12-74132012, 2012.

Emanuelsson, E. U., Hallquist, M., Kristensen, K., Glasius, M., Bohn, B., Fuchs, H., Kammer, B., Kiendler-Scharr, A., Nehr, S., Rubach, F., Tillmann, R., Wahner, A., Wu, H.-C., and Mentel, Th. F.: Formation of anthropogenic secondary organic aerosol (SOA) 
and its influence on biogenic SOA properties, Atmos. Chem. Phys., 13, 2837-2855, doi:10.5194/acp-13-2837-2013, 2013.

Engelhart, G. J., Asa-Awuku, A., Nenes, A., and Pandis, S. N.: CCN activity and droplet growth kinetics of fresh and aged monoterpene secondary organic aerosol, Atmos. Chem. Phys., 8, 39373949, doi:10.5194/acp-8-3937-2008, 2008.

Engelhart, G. J., Moore, R. H., Nenes, A., and Pandis, S. N.: Cloud condensation nuclei activity of isoprene secondary organic aerosol, J. Geophys. Res.-Atmos., 116, D02207, doi:10.1029/2010jd014706, 2011.

Flores, J. M., Zhao, D. F., Segev, L., Schlag, P., Kiendler-Scharr, A., Fuchs, H., Watne, ̊.. K., Bluvshtein, N., Mentel, Th. F., Hallquist, M., and Rudich, Y.: Evolution of the complex refractive index in the UV spectral region in ageing secondary organic aerosol, Atmos. Chem. Phys., 14, 5793-5806, doi:10.5194/acp14-5793-2014, 2014.

Frosch, M., Bilde, M., DeCarlo, P. F., Juranyi, Z., Tritscher, T., Dommen, J., Donahue, N. M., Gysel, M., Weingartner, E., and Baltensperger, U.: Relating cloud condensation nuclei activity and oxidation level of alpha-pinene secondary organic aerosols, J. Geophys. Res.-Atmos., 116, D22212, doi:10.1029/2011jd016401, 2011.

Fuchs, H., Dorn, H.-P., Bachner, M., Bohn, B., Brauers, T., Gomm, S., Hofzumahaus, A., Holland, F., Nehr, S., Rohrer, F., Tillmann, R., and Wahner, A.: Comparison of $\mathrm{OH}$ concentration measurements by DOAS and LIF during SAPHIR chamber experiments at high $\mathrm{OH}$ reactivity and low NO concentration, Atmos. Meas. Tech., 5, 1611-1626, doi:10.5194/amt-5-1611-2012, 2012.

Gao, S., Keywood, M., Ng, N. L., Surratt, J., Varutbangkul, V., Bahreini, R., Flagan, R. C., and Seinfeld, J. H.: Low-molecularweight and oligomeric components in secondary organic aerosol from the ozonolysis of cycloalkenes and alpha-pinene, J. Phys. Chem. A, 108, 10147-10164, doi:10.1021/jp047466e, 2004.

Glasius, M., la Cour, A., and Lohse, C.: Fossil and nonfossil carbon in fine particulate matter: A study of five European cities, J. Geophys. Res.-Atmos., 116, D11302, doi:10.1029/2011jd015646, 2011.

Goldstein, A. H. and Galbally, I. E.: Known and unexplored organic constituents in the earth's atmosphere, Environ. Sci. Technol., 41, 1514-1521, doi:10.1021/es072476p, 2007.

Goldstein, A. H., Koven, C. D., Heald, C. L., and Fung, I. Y.: Biogenic carbon and anthropogenic pollutants combine to form a cooling haze over the southeastern United States, P. Natl. Acad. Sci. USA, 106, 8835-8840, doi:10.1073/pnas.0904128106, 2009.

Good, N., Topping, D. O., Duplissy, J., Gysel, M., Meyer, N. K., Metzger, A., Turner, S. F., Baltensperger, U., Ristovski, Z., Weingartner, E., Coe, H., and McFiggans, G.: Widening the gap between measurement and modelling of secondary organic aerosol properties?, Atmos. Chem. Phys., 10, 2577-2593, doi:10.5194/acp-10-2577-2010, 2010.

Guenther, A. B., Jiang, X., Heald, C. L., Sakulyanontvittaya, T., Duhl, T., Emmons, L. K., and Wang, X.: The Model of Emissions of Gases and Aerosols from Nature version 2.1 (MEGAN2.1): an extended and updated framework for modeling biogenic emissions, Geosci. Model Dev., 5, 1471-1492, doi:10.5194/gmd-51471-2012, 2012.

Hallquist, M., Wenger, J. C., Baltensperger, U., Rudich, Y., Simpson, D., Claeys, M., Dommen, J., Donahue, N. M., George,
C., Goldstein, A. H., Hamilton, J. F., Herrmann, H., Hoffmann, T., Iinuma, Y., Jang, M., Jenkin, M. E., Jimenez, J. L., Kiendler-Scharr, A., Maenhaut, W., McFiggans, G., Mentel, Th. F., Monod, A., Prévôt, A. S. H., Seinfeld, J. H., Surratt, J. D., Szmigielski, R., and Wildt, J.: The formation, properties and impact of secondary organic aerosol: current and emerging issues, Atmos. Chem. Phys., 9, 5155-5236, doi:10.5194/acp-9-51552009, 2009.

Hamilton, J. F., Webb, P. J., Lewis, A. C., and Reviejo, M. M.: Quantifying small molecules in secondary organic aerosol formed during the photo-oxidation of toluene with hydroxyl radicals, Atmos. Environ., 39, 7263-7275, doi:10.1016/j.atmosenv.2005.09.006, 2005.

Hansen, A. M. K., Hong, J., Raatikainen, T., Kristensen, K., Ylisirniö, A., Virtanen, A., Petäjä, T., Glasius, M., and Prisle, N. L.: Hygroscopic properties and cloud condensation nuclei activation of limonene-derived organosulfates and their mixtures with ammonium sulfate, Atmos. Chem. Phys., 15, 14071-14089, doi:10.5194/acp-15-14071-2015, 2015.

Heald, C. L., Jacob, D. J., Park, R. J., Russell, L. M., Huebert, B. J., Seinfeld, J. H., Liao, H., and Weber, R. J.: A large organic aerosol source in the free troposphere missing from current models, Geophys. Res. Lett., 32, L18809, doi:10.1029/2005g1023831, 2005.

Hildebrandt, L., Donahue, N. M., and Pandis, S. N.: High formation of secondary organic aerosol from the photo-oxidation of toluene, Atmos. Chem. Phys., 9, 2973-2986, doi:10.5194/acp-92973-2009, 2009.

Hildebrandt, L., Henry, K. M., Kroll, J. H., Worsnop, D. R., Pandis, S. N., and Donahue, N. M.: Evaluating the Mixing of Organic Aerosol Components Using High-Resolution Aerosol Mass Spectrometry, Environ. Sci. Technol., 45, 6329-6335, doi:10.1021/es200825g, 2011.

Hoyle, C. R., Boy, M., Donahue, N. M., Fry, J. L., Glasius, M., Guenther, A., Hallar, A. G., Huff Hartz, K., Petters, M. D., Petäjä, T., Rosenoern, T., and Sullivan, A. P.: A review of the anthropogenic influence on biogenic secondary organic aerosol, Atmos. Chem. Phys., 11, 321-343, doi:10.5194/acp-11-321-2011, 2011.

Irwin, M., Good, N., Crosier, J., Choularton, T. W., and McFiggans, G.: Reconciliation of measurements of hygroscopic growth and critical supersaturation of aerosol particles in central Germany, Atmos. Chem. Phys., 10, 11737-11752, doi:10.5194/acp10-11737-2010, 2010.

Jenkin, M. E., Saunders, S. M., Wagner, V., and Pilling, M. J.: Protocol for the development of the Master Chemical Mechanism, MCM v3 (Part B): tropospheric degradation of aromatic volatile organic compounds, Atmos. Chem. Phys., 3, 181-193, doi:10.5194/acp-3-181-2003, 2003.

Jimenez, J. L., Canagaratna, M. R., Donahue, N. M., Prevot, A. S. H., Zhang, Q., Kroll, J. H., DeCarlo, P. F., Allan, J. D., Coe, H., Ng, N. L., Aiken, A. C., Docherty, K. S., Ulbrich, I. M., Grieshop, A. P., Robinson, A. L., Duplissy, J., Smith, J. D., Wilson, K. R., Lanz, V. A., Hueglin, C., Sun, Y. L., Tian, J., Laaksonen, A., Raatikainen, T., Rautiainen, J., Vaattovaara, P., Ehn, M., Kulmala, M., Tomlinson, J. M., Collins, D. R., Cubison, M. J., Dunlea, E. J., Huffman, J. A., Onasch, T. B., Alfarra, M. R., Williams, P. I., Bower, K., Kondo, Y., Schneider, J., Drewnick, F., Borrmann, S., Weimer, S., Demerjian, K., Salcedo, D., Cottrell, L., Griffin, R., Takami, A., Miyoshi, T., Hatakeyama, S., Shimono, A., Sun, J. Y., Zhang, Y. M., Dzepina, K., Kimmel, 
J. R., Sueper, D., Jayne, J. T., Herndon, S. C., Trimborn, A. M., Williams, L. R., Wood, E. C., Middlebrook, A. M., Kolb, C. E., Baltensperger, U., and Worsnop, D. R.: Evolution of Organic Aerosols in the Atmosphere, Science, 326, 1525-1529, doi:10.1126/science.1180353, 2009.

Johnson, D., Jenkin, M. E., Wirtz, K., and Martin-Reviejo, M.: Simulating the formation of secondary organic aerosol from the photooxidation of aromatic hydrocarbons, Environ. Chem., 2, 35-48, doi:10.1071/en04079, 2005.

Jordan, A., Haidacher, S., Hanel, G., Hartungen, E., Mark, L., Seehauser, H., Schottkowsky, R., Sulzer, P., and Mark, T. D.: A high resolution and high sensitivity proton-transfer-reaction time-offlight mass spectrometer (PTR-TOF-MS), Int. J. Mass Spectrom., 286, 122-128, doi:10.1016/j.ijms.2009.07.005, 2009.

Juranyi, Z., Gysel, M., Duplissy, J., Weingartner, E., Tritscher, T., Dommen, J., Henning, S., Ziese, M., Kiselev, A., Stratmann, F., George, I., and Baltensperger, U.: Influence of gas-to-particle partitioning on the hygroscopic and droplet activation behaviour of alpha-pinene secondary organic aerosol, Phys. Chem. Chem. Phys., 11, 8091-8097, doi:10.1039/b904162a, 2009.

Kalberer, M., Paulsen, D., Sax, M., Steinbacher, M., Dommen, J., Prevot, A. S. H., Fisseha, R., Weingartner, E., Frankevich, V., Zenobi, R., and Baltensperger, U.: Identification of polymers as major components of atmospheric organic aerosols, Science, 303, 1659-1662, doi:10.1126/science.1092185, 2004.

Kaminiski, M.: Untersuchung des photochemischen Terpenoidabbaus in der Atmosphärensimulationskammer SAPHIR, Ph.D. , Institut für Physikalische Chemie, Universität zu Köln, Jülich, 2014.

Kanakidou, M., Seinfeld, J. H., Pandis, S. N., Barnes, I., Dentener, F. J., Facchini, M. C., Van Dingenen, R., Ervens, B., Nenes, A., Nielsen, C. J., Swietlicki, E., Putaud, J. P., Balkanski, Y., Fuzzi, S., Horth, J., Moortgat, G. K., Winterhalter, R., Myhre, C. E. L., Tsigaridis, K., Vignati, E., Stephanou, E. G., and Wilson, J.: Organic aerosol and global climate modelling: a review, Atmos. Chem. Phys., 5, 1053-1123, doi:10.5194/acp-5-1053-2005, 2005.

Koop, T., Bookhold, J., Shiraiwa, M., and Poeschl, U.: Glass transition and phase state of organic compounds: dependency on molecular properties and implications for secondary organic aerosols in the atmosphere, Phys. Chem. Chem. Phys., 13, 19238-19255, doi:10.1039/c1cp22617g, 2011.

Kourtchev, I., Fuller, S., Aalto, J., Ruuskanen, T. M., McLeod, M. W., Maenhaut, W., Jones, R., Kulmala, M., and Kalberer, M.: Molecular Composition of Boreal Forest Aerosol from Hyytiala, Finland, Using Ultrahigh Resolution Mass Spectrometry, Environ. Sci. Technol., 47, 4069-4079, doi:10.1021/es3051636, 2013.

Kourtchev, I., O’Connor, I. P., Giorio, C., Fuller, S. J., Kristensen, K., Maenhaut, W., Wenger, J. C., Sodeau, J. R., Glasius, M., and Kalberer, M.: Effects of anthropogenic emissions on the molecular composition of urban organic aerosols: An ultrahigh resolution mass spectrometry study, Atmos. Environ., 89, 525-532, doi:10.1016/j.atmosenv.2014.02.051, 2014.

Kourtchev, I., Doussin, J.-F., Giorio, C., Mahon, B., Wilson, E. M., Maurin, N., Pangui, E., Venables, D. S., Wenger, J. C., and Kalberer, M.: Molecular composition of fresh and aged secondary organic aerosol from a mixture of biogenic volatile compounds: a high-resolution mass spectrometry study, Atmos.
Chem. Phys., 15, 5683-5695, doi:10.5194/acp-15-5683-2015, 2015.

Kristensen, K. and Glasius, M.: Organosulfates and oxidation products from biogenic hydrocarbons in fine aerosols from a forest in North West Europe during spring, Atmos. Environ., 45, 45464556, doi:10.1016/j.atmosenv.2011.05.063, 2011.

Kroll, J. H. and Seinfeld, J. H.: Chemistry of secondary organic aerosol: Formation and evolution of low-volatility organics in the atmosphere, Atmos. Environ., 42, 3593-3624, doi:10.1016/j.atmosenv.2008.01.003, 2008.

Lamarque, J.-F., Bond, T. C., Eyring, V., Granier, C., Heil, A., Klimont, Z., Lee, D., Liousse, C., Mieville, A., Owen, B., Schultz, M. G., Shindell, D., Smith, S. J., Stehfest, E., Van Aardenne, J., Cooper, O. R., Kainuma, M., Mahowald, N., McConnell, J. R., Naik, V., Riahi, K., and van Vuuren, D. P.: Historical (1850-2000) gridded anthropogenic and biomass burning emissions of reactive gases and aerosols: methodology and application, Atmos. Chem. Phys., 10, 7017-7039, doi:10.5194/acp10-7017-2010, 2010.

Lambe, A. T., Onasch, T. B., Massoli, P., Croasdale, D. R., Wright, J. P., Ahern, A. T., Williams, L. R., Worsnop, D. R., Brune, W. H., and Davidovits, P.: Laboratory studies of the chemical composition and cloud condensation nuclei (CCN) activity of secondary organic aerosol (SOA) and oxidized primary organic aerosol (OPOA), Atmos. Chem. Phys., 11, 8913-8928, doi:10.5194/acp11-8913-2011, 2011.

Lance, S., Medina, J., Smith, J. N., and Nenes, A.: Mapping the operation of the DMT Continuous Flow CCN counter, Aerosol Sci Technol., 40, 242-254, doi:10.1080/02786820500543290, 2006.

Low, R. D. H.: A Generalized Equation for the Solution Effect in Droplet Growth, J. Atmos. Sci., 26, 608-611, doi:10.1175/15200469(1969)026<0608:AGEFTS>2.0.CO;2, 1969.

Loza, C. L., Coggon, M. M., Nguyen, T. B., Zuend, A., Flagan, R. C., and Seinfeld, J. H.: On the Mixing and Evaporation of Secondary Organic Aerosol Components, Environ. Sci. Technol., 47, 6173-6180, doi:10.1021/es400979k, 2013.

Massoli, P., Lambe, A. T., Ahern, A. T., Williams, L. R., Ehn, M., Mikkila, J., Canagaratna, M. R., Brune, W. H., Onasch, T. B., Jayne, J. T., Petaja, T., Kulmala, M., Laaksonen, A., Kolb, C. E., Davidovits, P., and Worsnop, D. R.: Relationship between aerosol oxidation level and hygroscopic properties of laboratory generated secondary organic aerosol (SOA) particles, Geophys. Res. Lett., 37, L24801, doi:10.1029/2010g1045258, 2010.

McDonald, J. E.: Erroneous cloud-phy sics applications of raoult's law, J. Meteorol., 10, 68-70, doi:10.1175/15200469(1953)010<0068:ECPSAO>2.0.CO;2, 1953.

Moore, R. H., Nenes, A., and Medina, J.: Scanning Mobility CCN Analysis-A Method for Fast Measurements of Size-Resolved CCN Distributions and Activation Kinetics, Aerosol Sci. Technol., 44, 861-871, doi:10.1080/02786826.2010.498715, 2010.

Ng, N. L., Chhabra, P. S., Chan, A. W. H., Surratt, J. D., Kroll, J. H., Kwan, A. J., McCabe, D. C., Wennberg, P. O., Sorooshian, A., Murphy, S. M., Dalleska, N. F., Flagan, R. C., and Seinfeld, J. H.: Effect of $\mathrm{NO}_{x}$ level on secondary organic aerosol (SOA) formation from the photooxidation of terpenes, Atmos. Chem. Phys., 7, 5159-5174, doi:10.5194/acp-7-5159-2007, 2007a.

Ng, N. L., Kroll, J. H., Chan, A. W. H., Chhabra, P. S., Flagan, R. C., and Seinfeld, J. H.: Secondary organic aerosol formation 
from m-xylene, toluene, and benzene, Atmos. Chem. Phys., 7, 3909-3922, doi:10.5194/acp-7-3909-2007, 2007b.

Noziere, B., Kaberer, M., Claeys, M., Allan, J., D’Anna, B., Decesari, S., Finessi, E., Glasius, M., Grgic, I., Hamilton, J. F., Hoffmann, T., Iinuma, Y., Jaoui, M., Kahno, A., Kampf, C. J., Kourtchev, I., Maenhaut, W., Marsden, N., Saarikoski, S., Schnelle-Kreis, J., Surratt, J. D., Szidat, S., Szmigielski, R., and Wisthaler, A.: The Molecular Identification of Organic Compounds in the Atmosphere: State of the Art and Challenges, Chem. Rev., 115, 3919-3983, doi:10.1021/cr5003485, 2015.

Padró, L. T., Asa-Awuku, A., Morrison, R., and Nenes, A.: Inferring thermodynamic properties from $\mathrm{CCN}$ activation experiments: single-component and binary aerosols, Atmos. Chem. Phys., 7, 5263-5274, doi:10.5194/acp-7-5263-2007, 2007.

Petrucci, H. and Herring, M.: General Chemistry, Principles \& Modern Applications, 9th ed., Pearson Education, Inc., Upper Saddle River, NJ, 2007.

Petters, M. D. and Kreidenweis, S. M.: A single parameter representation of hygroscopic growth and cloud condensation nucleus activity, Atmos. Chem. Phys., 7, 1961-1971, doi:10.5194/acp-71961-2007, 2007.

Petters, M. D., Wex, H., Carrico, C. M., Hallbauer, E., Massling, A., McMeeking, G. R., Poulain, L., Wu, Z., Kreidenweis, S. M., and Stratmann, F.: Towards closing the gap between hygroscopic growth and activation for secondary organic aerosol - Part 2: Theoretical approaches, Atmos. Chem. Phys., 9, 3999-4009, doi:10.5194/acp-9-3999-2009, 2009.

Prenni, A. J., Petters, M. D., Kreidenweis, S. M., DeMott, P. J., and Ziemann, P. J.: Cloud droplet activation of secondary organic aerosol, J. Geophys. Res.-Atmos., 112, D10223, doi:10.1029/2006jd007963, 2007.

Presto, A. A., Hartz, K. E. H., and Donahue, N. M.: Secondary organic aerosol production from terpene ozonolysis. 2. Effect of NOx concentration, Environ. Sci. Technol., 39, 7046-7054, doi:10.1021/es050400s, 2005.

Prisle, N. L., Raatikainen, T., Sorjamaa, R., Svenningsson, B., Laaksonen, A., and Bilde, M.: Surfactant partitioning in cloud droplet activation: a study of $\mathrm{C} 8, \mathrm{C} 10, \mathrm{C} 12$ and $\mathrm{C} 14$ normal fatty acid sodium salts, Tellus Ser. B-Chem. Phys. Meteorol., 60, 416-431, doi:10.1111/j.1600-0889.2008.00352.x, 2008.

Rickards, A. M. J., Miles, R. E. H., Davies, J. F., Marshall, F. H., and Reid, J. P.: Measurements of the Sensitivity of Aerosol Hygroscopicity and the kappa Parameter to the O/C Ratio, J. Phys. Chem. A, 117, 14120-14131, doi:10.1021/jp407991n, 2013.

Rohrer, F., Bohn, B., Brauers, T., Brüning, D., Johnen, F.-J., Wahner, A., and Kleffmann, J.: Characterisation of the photolytic HONO-source in the atmosphere simulation chamber SAPHIR, Atmos. Chem. Phys., 5, 2189-2201, doi:10.5194/acp-5-21892005, 2005.

Rose, D., Gunthe, S. S., Mikhailov, E., Frank, G. P., Dusek, U., Andreae, M. O., and Pöschl, U.: Calibration and measurement uncertainties of a continuous-flow cloud condensation nuclei counter (DMT-CCNC): $\mathrm{CCN}$ activation of ammonium sulfate and sodium chloride aerosol particles in theory and experiment, Atmos. Chem. Phys., 8, 1153-1179, doi:10.5194/acp-8-11532008, 2008.

Shantz, N. C., Chang, R. Y.-W., Slowik, J. G., Vlasenko, A., Abbatt, J. P. D., and Leaitch, W. R.: Slower CCN growth kinetics of anthropogenic aerosol compared to biogenic aerosol observed at a rural site, Atmos. Chem. Phys., 10, 299-312, doi:10.5194/acp10-299-2010, 2010.

Shantz, N. C., Pierce, J. R., Chang, R. Y. W., Vlasenko, A., Riipinen, I., Sjostedt, S., Slowik, J. G., Wiebe, A., Liggio, J., Abbatt, J. P. D., and Leaitch, W. R.: Cloud condensation nuclei droplet growth kinetics of ultrafine particles during anthropogenic nucleation events, Atmos. Environ., 47, 389-398, doi:10.1016/j.atmosenv.2011.10.049, 2012.

Shilling, J. E., Zaveri, R. A., Fast, J. D., Kleinman, L., Alexander, M. L., Canagaratna, M. R., Fortner, E., Hubbe, J. M., Jayne, J. T., Sedlacek, A., Setyan, A., Springston, S., Worsnop, D. R., and Zhang, Q.: Enhanced SOA formation from mixed anthropogenic and biogenic emissions during the CARES campaign, Atmos. Chem. Phys., 13, 2091-2113, doi:10.5194/acp-13-20912013, 2013.

Spracklen, D. V., Jimenez, J. L., Carslaw, K. S., Worsnop, D. R., Evans, M. J., Mann, G. W., Zhang, Q., Canagaratna, M. R., Allan, J., Coe, H., McFiggans, G., Rap, A., and Forster, P.: Aerosol mass spectrometer constraint on the global secondary organic aerosol budget, Atmos. Chem. Phys., 11, 12109-12136, doi:10.5194/acp-11-12109-2011, 2011.

Suda, S. R., Petters, M. D., Yeh, G. K., Strollo, C., Matsunaga, A., Faulhaber, A., Ziemann, P. J., Prenni, A. J., Carrico, C. M., Sullivan, R. C., and Kreidenweis, S. M.: Influence of Functional Groups on Organic Aerosol Cloud Condensation Nucleus Activity, Environ. Sci. Technol., 48, 10182-10190, doi:10.1021/es502147y, 2014.

Tolocka, M. P., Jang, M., Ginter, J. M., Cox, F. J., Kamens, R. M., and Johnston, M. V.: Formation of oligomers in secondary organic aerosol, Environ. Sci. Technol., 38, 1428-1434, doi:10.1021/es035030r, 2004.

Topping, D., Connolly, P., and McFiggans, G.: Cloud droplet number enhanced by co-condensation of organic vapours, Nat. Geosci., 6, 443-446, doi:10.1038/ngeo1809, 2013.

Topping, D. O., McFiggans, G. B., and Coe, H.: A curved multicomponent aerosol hygroscopicity model framework: Part 2 - Including organic compounds, Atmos. Chem. Phys., 5, 1223-1242, doi:10.5194/acp-5-1223-2005, 2005.

Topping, D. O. and McFiggans, G.: Tight coupling of particle size, number and composition in atmospheric cloud droplet activation, Atmos. Chem. Phys., 12, 3253-3260, doi:10.5194/acp-12-32532012, 2012.

Tritscher, T., Dommen, J., DeCarlo, P. F., Gysel, M., Barmet, P. B., Praplan, A. P., Weingartner, E., Prévôt, A. S. H., Riipinen, I., Donahue, N. M., and Baltensperger, U.: Volatility and hygroscopicity of aging secondary organic aerosol in a smog chamber, Atmos. Chem. Phys., 11, 11477-11496, doi:10.5194/acp-1111477-2011, 2011.

Verma, V., Fang, T., Guo, H., King, L., Bates, J. T., Peltier, R. E., Edgerton, E., Russell, A. G., and Weber, R. J.: Reactive oxygen species associated with water-soluble $\mathrm{PM}_{2.5}$ in the southeastern United States: spatiotemporal trends and source apportionment, Atmos. Chem. Phys., 14, 12915-12930, doi:10.5194/acp14-12915-2014, 2014.

Virtanen, A., Joutsensaari, J., Koop, T., Kannosto, J., Yli-Pirila, P., Leskinen, J., Makela, J. M., Holopainen, J. K., Poeschl, U., Kulmala, M., Worsnop, D. R., and Laaksonen, A.: An amorphous solid state of biogenic secondary organic aerosol particles, Nature, 467, 824-827, doi:10.1038/nature09455, 2010. 
Weber, R. J., Sullivan, A. P., Peltier, R. E., Russell, A., Yan, B., Zheng, M., de Gouw, J., Warneke, C., Brock, C., Holloway, J. S., Atlas, E. L., and Edgerton, E.: A study of secondary organic aerosol formation in the anthropogenic-influenced southeastern United States, J. Geophys. Res.-Atmos., 112, D13302, doi:10.1029/2007jd008408, 2007.

Wex, H., Petters, M. D., Carrico, C. M., Hallbauer, E., Massling, A., McMeeking, G. R., Poulain, L., Wu, Z., Kreidenweis, S. M., and Stratmann, F.: Towards closing the gap between hygroscopic growth and activation for secondary organic aerosol: Part $1-$ Evidence from measurements, Atmos. Chem. Phys., 9, 3987-3997, doi:10.5194/acp-9-3987-2009, 2009.

Whitehead, J. D., Irwin, M., Allan, J. D., Good, N., and McFiggans, G.: A meta-analysis of particle water uptake reconciliation studies, Atmos. Chem. Phys., 14, 11833-11841, doi:10.5194/acp-1411833-2014, 2014

Wiedensohler, A.: An approximation of the bipolar chargedistribution for particles in the sub-micron size range, J. Aerosol Sci., 19, 387-389, doi:10.1016/0021-8502(88)90278-9, 1988.

Worton, D. R., Goldstein, A. H., Farmer, D. K., Docherty, K. S., Jimenez, J. L., Gilman, J. B., Kuster, W. C., de Gouw, J., Williams, B. J., Kreisberg, N. M., Hering, S. V., Bench, G., McKay, M., Kristensen, K., Glasius, M., Surratt, J. D., and Seinfeld, J. H.: Origins and composition of fine atmospheric carbonaceous aerosol in the Sierra Nevada Mountains, California, Atmos. Chem. Phys., 11, 10219-10241, doi:10.5194/acp-1110219-2011, 2011.

Xu, L., Guo, H. Y., Boyd, C. M., Klein, M., Bougiatioti, A., Cerully, K. M., Hite, J. R., Isaacman-VanWertz, G., Kreisberg, N. M., Knote, C., Olson, K., Koss, A., Goldstein, A. H., Hering, S. V., de Gouw, J., Baumann, K., Lee, S. H., Nenes, A., Weber, R. J., and $\mathrm{Ng}$, N. L.: Effects of anthropogenic emissions on aerosol formation from isoprene and monoterpenes in the southeastern United States, P. Natl. Acad. Sci. USA, 112, 37-42, doi:10.1073/pnas.1417609112, 2015.

Xu, W., Guo, S., Gomez-Hernandez, M., Zamora, M. L., Secrest, J., Marrero-Ortiz, W., Zhang, A. L., Collins, D. R., and Zhang, R. Y.: Cloud forming potential of oligomers relevant to secondary organic aerosols, Geophys. Res. Lett., 41, 6538-6545, doi:10.1002/2014g1061040, 2014.
Zhang, Q., Jimenez, J. L., Canagaratna, M. R., Ulbrich, I. M., Ng, N. L., Worsnop, D. R., and Sun, Y. L.: Understanding atmospheric organic aerosols via factor analysis of aerosol mass spectrometry: a review, Anal. Bioanal. Chem., 401, 3045-3067, doi:10.1007/s00216-011-5355-y, 2011.

Zhang, X., Cappa, C. D., Jathar, S. H., McVay, R. C., Ensberg, J. J., Kleeman, M. J., and Seinfeld, J. H.: Influence of vapor wall loss in laboratory chambers on yields of secondary organic aerosol, P. Natl. Acad. Sci. USA, 111, 5802-5807, doi:10.1073/pnas.1404727111, 2014.

Zhang, Y. Y., Müller, L., Winterhalter, R., Moortgat, G. K., Hoffmann, T., and Pöschl, U.: Seasonal cycle and temperature dependence of pinene oxidation products, dicarboxylic acids and nitrophenols in fine and coarse air particulate matter, Atmos. Chem. Phys., 10, 7859-7873, doi:10.5194/acp-10-7859-2010, 2010.

Zhao, D. F., Buchholz, A., Mentel, Th. F., Müller, K.-P., Borchardt, J., Kiendler-Scharr, A., Spindler, C., Tillmann, R., Trimborn, A., Zhu, T., and Wahner, A.: Novel method of generation of $\mathrm{Ca}\left(\mathrm{HCO}_{3}\right)_{2}$ and $\mathrm{CaCO}_{3}$ aerosols and first determination of hygroscopic and cloud condensation nuclei activation properties, Atmos. Chem. Phys., 10, 8601-8616, doi:10.5194/acp-10-86012010, 2010.

Zhao, D. F., Buchholz, A., Kortner, B., Schlag, P., Rubach, F., Kiendler-Scharr, A., Tillmann, R., Wahner, A., Flores, J. M., Rudich, Y., Watne, A. K., Hallquist, M., Wildt, J., and Mentel, T. F.: Size-dependent hygroscopicity parameter $(\kappa)$ and chemical composition of secondary organic cloud condensation nuclei, Geophys. Res. Lett., 42, 10920-10928, doi:10.1002/2015GL066497, 2015a.

Zhao, D. F., Kaminski, M., Schlag, P., Fuchs, H., Acir, I.-H., Bohn, B., Häseler, R., Kiendler-Scharr, A., Rohrer, F., Tillmann, R., Wang, M. J., Wegener, R., Wildt, J., Wahner, A., and Mentel, Th. F.: Secondary organic aerosol formation from hydroxyl radical oxidation and ozonolysis of monoterpenes, Atmos. Chem. Phys., 15, 991-1012, doi:10.5194/acp-15-991-2015, 2015 b.

Zotter, P., Ciobanu, V. G., Zhang, Y. L., El-Haddad, I., Macchia, M., Daellenbach, K. R., Salazar, G. A., Huang, R.-J., Wacker, L., Hueglin, C., Piazzalunga, A., Fermo, P., Schwikowski, M., Baltensperger, U., Szidat, S., and Prévôt, A. S. H.: Radiocarbon analysis of elemental and organic carbon in Switzerland during winter-smog episodes from 2008 to 2012 - Part 1: Source apportionment and spatial variability, Atmos. Chem. Phys., 14, 1355113570, doi:10.5194/acp-14-13551-2014, 2014. 